\title{
Análise Comparativa entre Formas de Armazenamento e Distribuição de Escovas e Dentifrícios em Programas Educativos Preventivos Odontológicos para Escolares
}

Dissertação apresentada à Faculdade de Odontologia de Bauru, da Universidade de São Paulo, como parte dos requisitos para obtenção do título de Mestre em Odontologia, área de Saúde Coletiva.

(Edição Revisada) 


\section{Análise Comparativa entre Formas de Armazenamento e Distribuição de Escovas e Dentifrícios em Programas Educativos Preventivos Odontológicos para Escolares}

Dissertação apresentada à Faculdade de Odontologia de Bauru, da Universidade de São Paulo, como parte dos requisitos para obtenção do título de Mestre em Odontologia, área de Saúde Coletiva.

Orientadora: Prof $^{\mathrm{a}}$ Dra. Magali de Lourdes Caldana 


\begin{tabular}{|l}
\hline V711a \\
Vilhena, Fabiano Vieira \\
Análise comparativa entre formas de \\
armazenamento e distribuição de escovas e \\
dentifrícios dentais em programas educativos \\
preventivos odontológicos para escolares I \\
Fabiano Vieira Vilhena. - Bauru, 2005. \\
xii, 87 p. : il. ; $30 \mathrm{~cm}$. \\
Dissertação (Mestrado) -- Faculdade de \\
Odontologia de Bauru. Universidade de São \\
Paulo. \\
Orientador: Profa. Dra. Magali de Lourdes \\
Caldana
\end{tabular}

Autorizo, exclusivamente para fins
acadêmicos e científicos, a reprodução total ou
parcial desta dissertação, por processos
fotocopiadores e lou meios eletrônicos.
Assinatura do autor: Fabiano Vieira Vilhena
$04 / 02 / 2004$

Comitê de Ética da FOB : Projeto de pesquisa aprovado data: 21/09/2004

$\mathrm{N}^{\circ}$ do protocolo $-92 / 2004$

$21 / 09 / 2004$ 
FABIANO VIEIRA VILHENA

\begin{tabular}{|c|c|}
\hline 06/06/1973 & $\begin{array}{c}\text { Nascimento } \\
\text { São José dos Campos - SP }\end{array}$ \\
\hline $1992-1996$ & $\begin{array}{l}\text { Curso de Odontologia } \\
\text { Escola de Farmácia e Odontologia de Alfenas - MG }\end{array}$ \\
\hline $1997-1998$ & $\begin{array}{l}\text { Coordenador de saúde bucal } \\
\text { do município de General Carneiro - MT }\end{array}$ \\
\hline 1998 - 2004 & $\begin{array}{c}\text { Coordenador do Programa Oralls de Odontologia Escolar } \\
\text { desenvolvida pela empresa Oralls - Saúde Coletiva }\end{array}$ \\
\hline $2001-2003$ & $\begin{array}{l}\text { Curso de Especialização em Saúde Coletiva - APCD - } \\
\text { São José dos Campos - SP }\end{array}$ \\
\hline $1999-2004$ & $\begin{array}{l}\text { Professor de Odontologia Preventiva dos Cursos de } \\
\text { Especialização em Saúde Coletiva das APCDs de Bauru e } \\
\text { São José dos Campos, e do Hospital de Reabilitação de } \\
\text { Anomalias Craniofaciais - Centrinho - USP }\end{array}$ \\
\hline Associações & $\begin{array}{c}\text { APCD - Associação Paulista de Cirurgiões Dentistas } \\
\text { ABO - Associação Brasileira de Odontologia } \\
\text { ABOPREV - Associação Brasileira de Promoção de Saúde }\end{array}$ \\
\hline
\end{tabular}


"Ghegaria dias em que os jovens compreenderia a etiologia e a patologia da cárie dental e serixo capares de combater seus efeitos destrutivos através da medicacáo.

Blach 1895. 


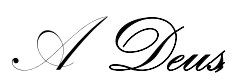

a Quem nos momentos mais incertos me oferecen amperio e certera de continuar.

- Oos meus pais Sülio e Maria Lusias

os quais me concederam o dom da vidas, o hoje me afroiam e me firofioicionam a ofortunidade deste momento.

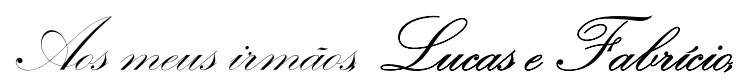
que mesmo distantes me incentivam e toicem muito foo mim.

- Aminha namorada Maria Gristina. que me ofereceu cainhte, atenciar o afwoio nesta nova elafea da minha vida dedico este Trabalho. 
Agradecimentos

- Orufa. Dra. Magali de Lourdes Gablana pelos ensinamentos afucio - dedicascio na ovientagiá deste buablho.

- Mo Prof. Di. Fose Roberto de Magathaies Bastos pela oportunidude de ensinar e desfecitar a interesse à verdadecira Odontologia na qual acredito.

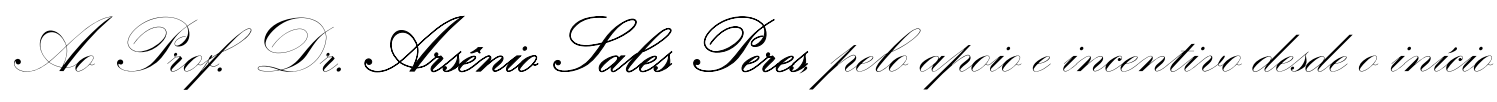
nos caminh hos escolhiclos.

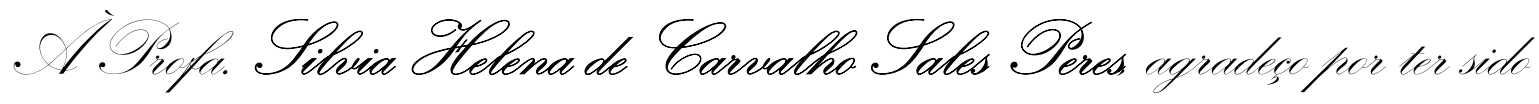
a grande colaboradora o incontivadora dos mous bablathos a qual som cla naio alingiria meus objelivos.

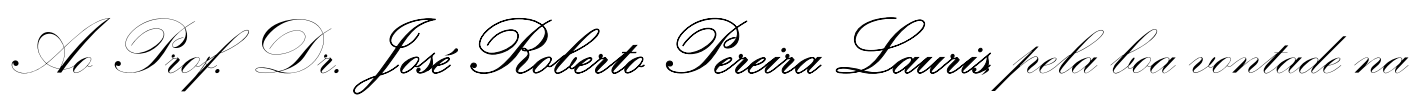
realisacaio das análises estalisticas e felos conhecimentos leasmilidos.

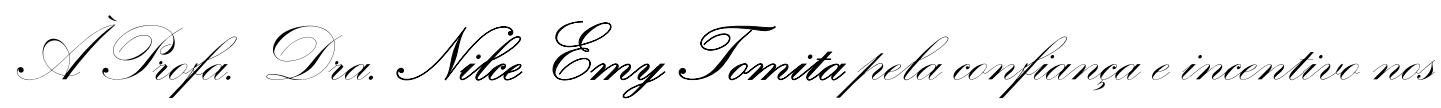
meus buabalhos.

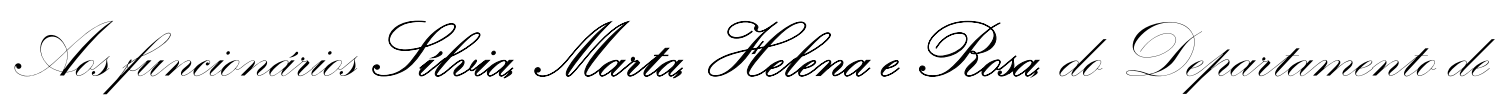

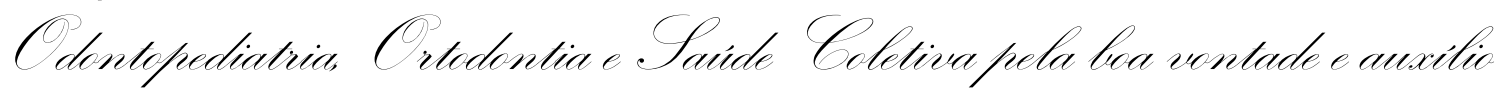
na conclusiá desta dafa.

vi 
- Lodos os amigos mestrandos doutorandos futwros mestrandos e amigos de

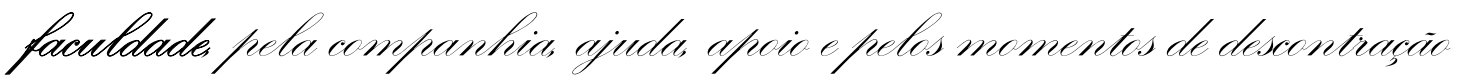
durante esta estada em. Bawru.

- Hos responsarveis pela higiene bucal dos escolares do meu trabatho e tambeim pelos escolares feda fundamental fraiticipacioio.

- Faculdade de Odontologia de Bawme na pessoa de sua Excelentissima Diretora. Profa. Ora. Maria Fidela de Lima Navairo. 


\section{SUMÁRIO}

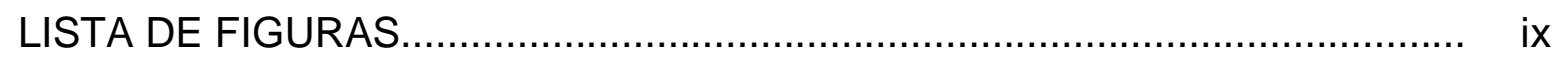

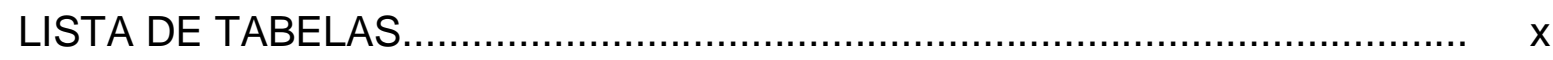

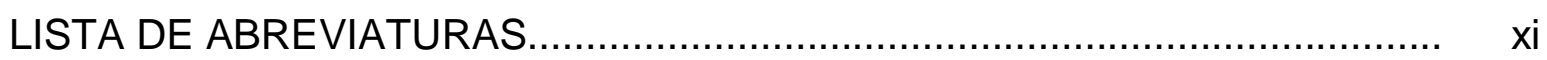

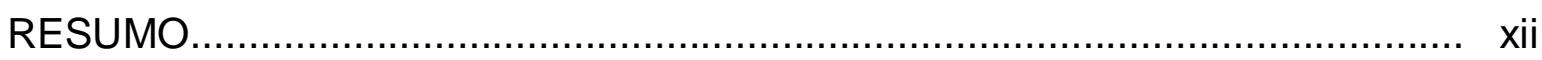

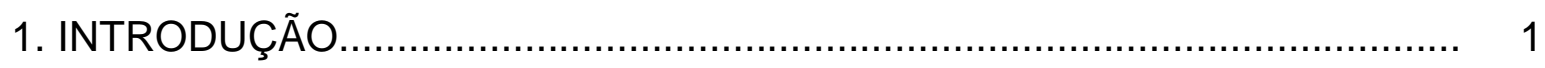

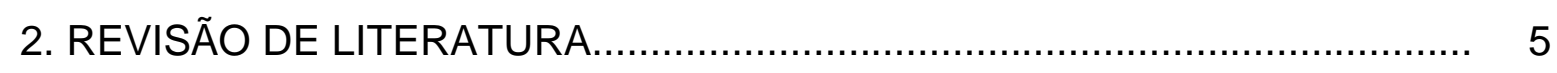

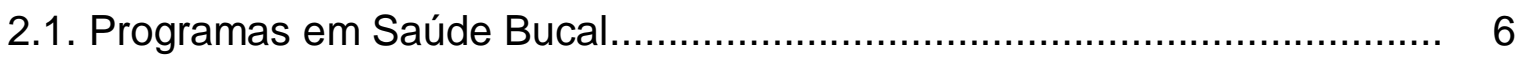

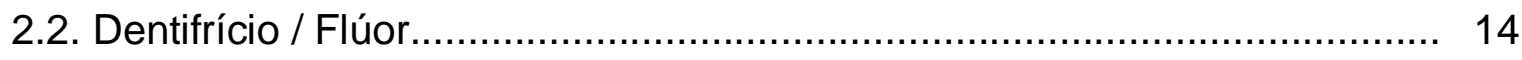

2.2.1. Considerações Gerais................................................. 14

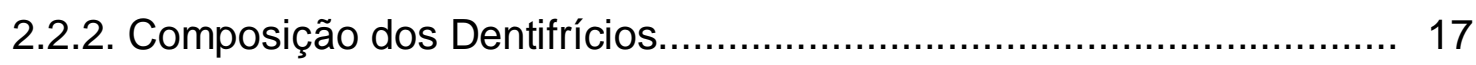

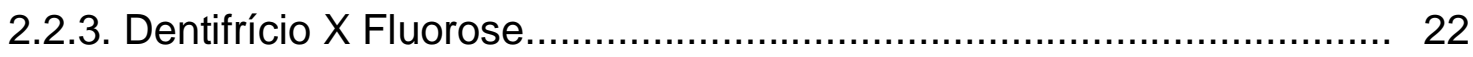

2.2.4. Uso Adequado do Dentifrício.................................................... 26

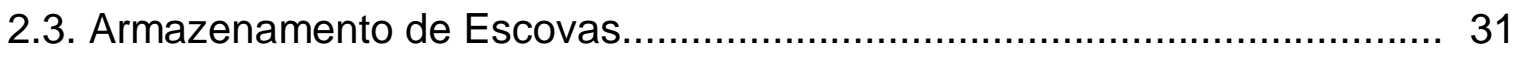

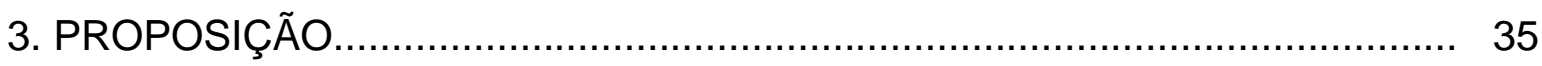

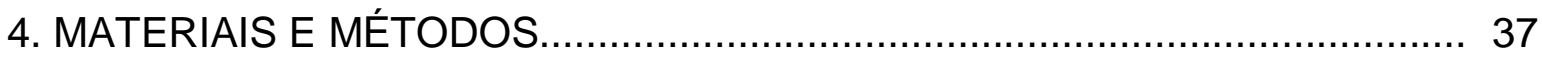

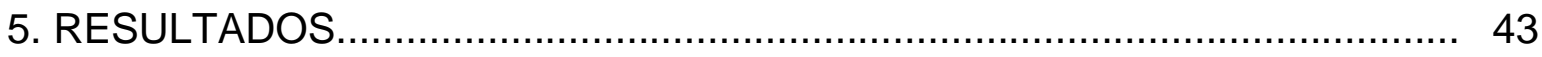

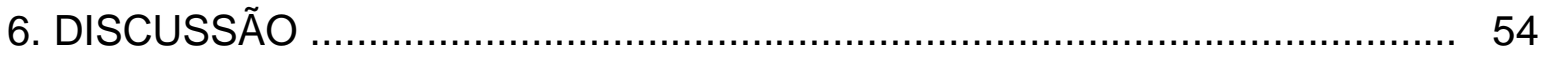

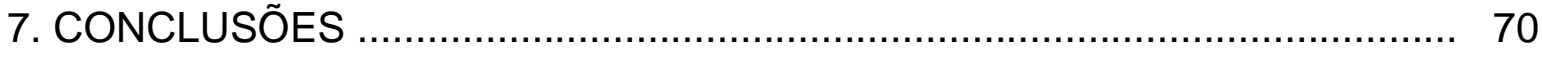

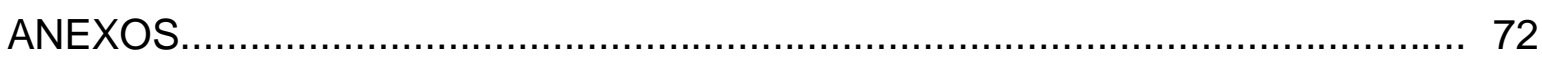

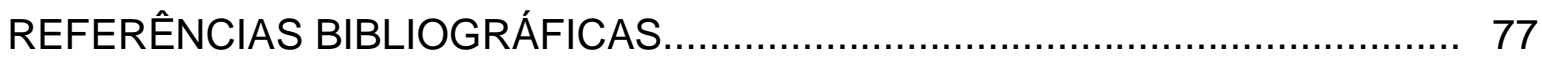

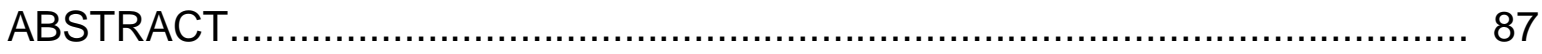




\section{LISTA DE FIGURAS}

Figura 1 - Ações educativas do Programa Oralls de Odontologia Escolar.

Figura 2 - Personagens lúdicos usados em programas odontológicos educativos preventivos.

Figura 3 - Técnica transversal.

Figura 4 - Técnica da tampa

Figura 5 - Kit de armazenamento coletivo de escovas e dentifrício líquido.

Figura 6 - Utilização do dentifrício líquido através da "técnica da gota".

Figura 7 - Desenho esquemático de confecção de porta escova coletivo

Figura 8 - Kit experimental número 5.

Figura 9 - Kit controle número 1

Figura 10 - Kit controle número 2.

Figura 11 - Kit controle número 3.

Figura 12 - Kit controle número 4

Figura 13 - Balança portátil de precisão em uso

Figura 14 - Comparação entre os kits quanto ao armazenamento

Figura 15 - Comparação entre os kits quanto a higiene.

Figura 16 - Comparação entre os kits quanto a praticidade.

Figura 17 - Quantidade de dentifrício aplicada nas técnicas "longitudinal”, "transversal" e "pouquinho", seguindo a ordem de cima para baixo.

Figura 18 - Criança aplicando o creme dental.

Figura 19 - Gráfico de tendências das quantidades dos dentifrícios dispensados por cada idade.

Figura 20 e 21 - Armazenamento em sala de aula do kit 5.

Figura 22 - Ilustração de "pequena" quantidade de pasta de dente que deveria ser usada. 


\section{LISTA DE TABELAS}

Tabela 1 - Seqüência da aplicação de dentifrícios........................................ 26

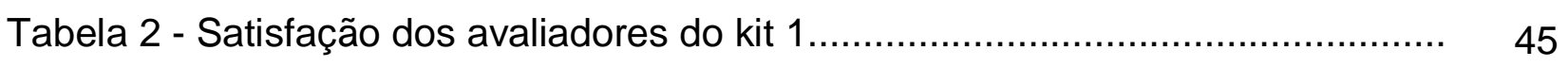

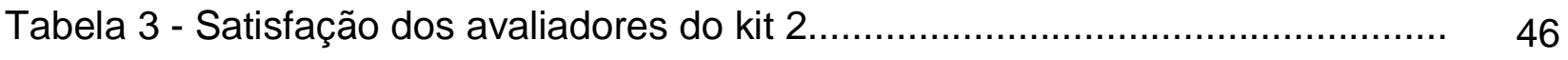

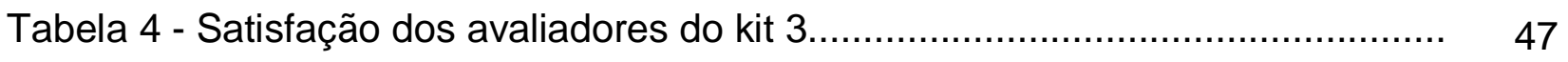

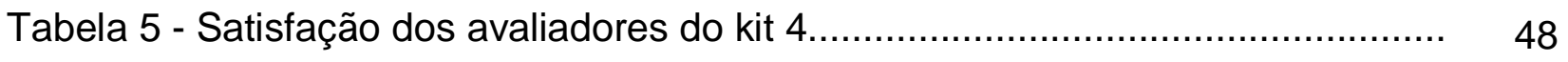

Tabela 6 - Médias dos escores obtidos em cada quesito avaliado em relação ao

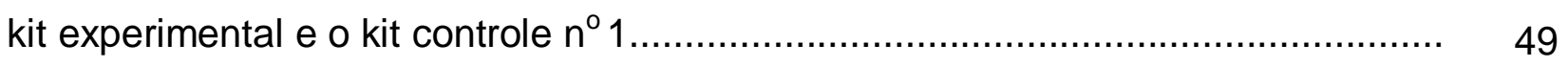

Tabela 7 - Médias dos escores obtidos em cada quesito avaliado em relação ao

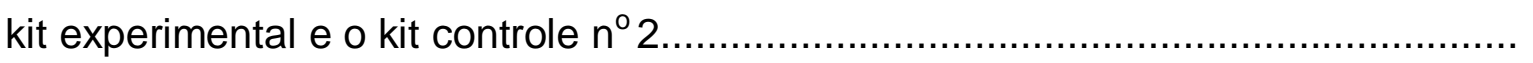

Tabela 8 - Médias dos escores obtidos em cada quesito avaliado em relação ao kit experimental e o kit controle $\mathrm{n}^{0} 3$........

Tabela 9 - Médias dos escores obtidos em cada quesito avaliado em relação ao

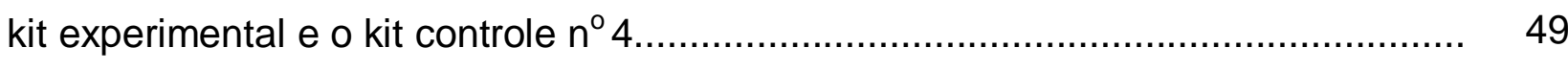

Tabela 10 - Média e desvio padrão da quantidade de cada dentifrício dispensada por cidade.

Tabela 11 - Relação de custos por aluno/ano em reais dos kits estudados para cada sala de aula com 40 alunos. 


\section{LISTA DE ABREVIATURAS}

\begin{tabular}{ll}
$>$ & superior a \\
$<$ & inferior a \\
SUS & contra \\
$\mathrm{F}^{-}$ & Sistema Único de Saúde \\
mgF/Kg/dia & Flúor \\
$\mathrm{g}$ & miligramas de flúor por quilo por dia \\
$\mathrm{ppm}$ & grama \\
$\mathrm{p}$ & partes por milhão \\
$\mathrm{r}$ & probabilidade \\
$\mathrm{F}$ & coeficiente de correlação \\
$\mathrm{cm}$ & estatística análise de ANCOVA \\
\hline
\end{tabular}




\section{RESUMO}

A proposta desse trabalho foi avaliar formas de armazenamento e distribuição do material higiene bucal utilizado nas escolas. Na primeira etapa participaram deste estudo, 20 avaliadores responsáveis pela higiene bucal dos escolares de Bauru e São José dos Campos. Estes responderam a dois questionários, anexos I e II, referentes a 5 kits de higiene bucal coletiva. A análise estatística desta etapa foi realizada por meio do teste Wilcoxon com significância de $p<0,05$. Como segunda etapa, 178 escolares de 4 a 8 anos de Bauru e Bariri participaram deste estudo, e cada criança aplicou uma quantidade de creme dental e dentifrício líquido para a prática da escovação. Uma balança portátil de precisão foi utilizada para pesar os dentifrícios dispensados. A análise estatística desta etapa foi obtida através do coeficiente de correlação de Pearson e a Análise de Covariância (ANCOVA) com nível de significância $p<0,05$. O kit 5, obteve graus de satisfação e muita satisfação quando comparados aos kits 1 à 4 (pouco satisfação e insatisfação). Na comparação direta entre os kits, o kit 5 demonstrou ter um custo bastante acessível, encontrando-se entre os mais baratos.

A quantidade de creme dental dispensada pelos escolares foi em média 0,41g em Bauru e 0,48g em Bariri. Não houve diferença estatística entre os escolares de Bauru e Bariri em relação ao dentifrício líquido, sendo a média dispensada pela amostra de 0,15g. O dentifrício líquido, através da "técnica da gota", pode ser facilmente utilizado dispensando uma pequena quantidade padronizada. O Kit 5 demonstrou ser a melhor forma de armazenamento e distribuição do material de higiene bucal do escolar, otimizando custos e obtendo melhores estratégias nos programas de saúde bucal coletiva. 


\section{INTRODUÇÃO}

A doença cárie atinge grande parte da população, mostrando alta prevalência desde idades precoces. De natureza infecciosa e transmissível, a cárie dentária constitui um relevante problema de saúde pública e individual para a maioria dos países. Sua causa se dá principalmente pelo hospedeiro, microbiota e dieta, os quais interagem num determinado tempo. Num contexto atual, a cárie dentária deve ser entendida como uma doença que ocasiona um desequilíbrio do processo des / remineralização, com perda de minerais do tecido dentário e formação da lesão cariosa. Esta perda de minerais é apenas o início de um processo que vai até a total destruição do dente. Estudos mais recentes têm mostrado que outros fatores, não envolvidos diretamente na formação da lesão, podem interferir também na doença cárie. Estes são conhecidos como fatores modificadores ou mascaradores, e compõem o meio onde a pessoa está inserida, seu nível sócio-econômico e seu nível de conhecimento (MALTZ; CARVALHO ${ }^{33}$ 1997, MALTZ $\left.{ }^{32}, 2000\right)$.

Além da cárie dentária, a gengivite e a periodontite são doenças provocadas por bactérias agregadas (placa bacteriana) que se instalam nos dentes. O controle da placa é realizado por vários meios que eliminam as bactérias e previnem novos ataques causados pelas mesmas, utilizando métodos mecânicos ou químicos (BUISHI; AXELSSON $\left.{ }^{10}, 1997\right)$.

Segundo MOSS ${ }^{34}, 1996$, crianças de até 8 anos de idade devem ser acompanhadas durante a escovação. Ainda de acordo com o autor, uma criança que não lava o rosto e as mãos não pode esconder tal proeza por muito tempo, 
pois as evidências são muito difíceis de esconder. Mas uma criança que não escova os dentes por um determinado período, pode fingir por um bom tempo.

A ausência de limpeza e escovação dentária é um fator de risco determinante para o desenvolvimento das doenças bucais (WALTER \& FERELLE $\left.{ }^{66}, 1997\right)$.

MOURA $^{35}$ et al., 2000, através de uma avaliação da eficácia de métodos de higiene bucal em crianças com todos os incisivos irrompidos, concluíram que a escova dental e o dentifrício foram os instrumentos mais eficazes na retirada da placa bacteriana.

Muitas são as dúvidas em relação a qual escova deve ser usada. A melhor escova é aquela em que o paciente melhor se adapta, visto que na literatura nenhuma diferença foi encontrada entre as marcas e modelos de escovas estudadas em se tratando da capacidade de remoção da placa bacteriana (WARREN ${ }^{67}$ et al, 2004).

$\mathrm{Na}$ verdade o que deve ser feito é aconselhar crianças em idade escolar a escovarem os seus dentes duas vezes ao dia com pasta fluoretada, pois a higienização parece exercer o melhor papel na prevenção das doenças bucais, do que apenas restringir os alimentos açucarados(GIBSON \& WILLIAMS $\left.{ }^{21}, 1999\right)$.

Para a ocorrência da lesão de cárie e periodontopatias é necessária a presença de placa bacteriana, dessa maneira, programas preventivos devem incluir orientação de higiene bucal e motivação, para que indivíduos sadios possam estar motivados a manter - se em saúde (KRAMER ${ }^{26}$ et al., 2001).

Ao mesmo tempo em que a escovação dentária com dentifrício fluoretado é uma das ações que contribuíram para o declínio da cárie nos últimos anos, principalmente através dos programas preventivos (PINTO $\left.{ }^{42}, 2000\right)$, ela também 
passa a ser a grande preocupação e a principal via de aumento da fluorose dentária. Através da incorporação do $\mathrm{F}^{-}$ao dentifrício, o uso descontrolado da quantidade de pasta dental utilizada por crianças de baixa idade, favorece a deglutição de grande quantidade de flúor, já que nesta idade a criança não sabe a quantidade a ser colocada e também não sabe que o dentifrício não deve ser ingerido (SÃO PAULO, Secretaria de Estado da Saúde $\left.{ }^{48}, 2002\right)$.

Mesmo com o risco de fluorose o uso do dentifrício fluoretado deve ser indicado. O seu uso de maneira controlada não oferece risco a saúde. Daí a importância dos programas educativos preventivos em saúde bucal para escolares, os quais além da educação em saúde bucal, estabelece uma rotina de escovação supervisionada (VILHENA $\left.{ }^{61}, 2001\right)$.

Tão importante quanto o uso do material de higiene bucal, através da prática da escovação dentária, é a forma de armazená-lo.

Com base nas considerações acima, este trabalho tem o objetivo de discutir a forma mais adequada de armazenamento e distribuição do material para à prática de higiene bucal, a fim de desenvolver um melhor aproveitamento das ações odontológicas preventivas em ambiente escolar. 


\section{REVISÃO DE LITERATURA}

A revisão de literatura foi realizada procurando enfocar os aspectos de Programas em Saúde Bucal, Dentifrícios e armazenamento de escovas, os quais foram descritos a seguir.

\subsection{Programas em Saúde Bucal}

O termo programa foi definido como um conjunto orgânico de projetos e atividades, que não representa necessariamente, limites rígidos para o seu tempo de execução, e permite a concretização do projeto de planejamento. É importante diferenciá-lo do significado de projeto, que é um instrumento de programação, geralmente tem um período limitado e caracteriza-se por objetos e metas quantificadas a serem cumpridas. O modelo de atenção à saúde bucal vem considerando como estratégico para a definição de sua atuação o conhecimento da realidade local, parte imprescindível do processo de planejamento (FRAZÃO; NARVAI $\left.{ }^{19}, 1996\right)$.

Desde que os métodos preventivos existentes contra a cárie dentária e a doença periodontal, passaram a ser de fácil aplicação e implementação, sob o ponto de vista da tecnologia e de baixo custo, as barreiras para a sua aplicação em massa passaram a ser motivos políticos e administrativos, isto é cada governo e cada programa odontológico prioriza o que melhor Ihe convir $\left(\right.$ PINTO $\left.^{42}, 2000\right)$.

Um exemplo de iniciativa política positiva a nível local, foi à lei municipal $\mathrm{n}^{\circ}$ 3979/1991 de 19/12/1991 ${ }^{47}$, que instituiu a obrigatoriedade da escovação dentária diária supervisionada nas unidades escolares da rede municipal de ensino do 
município de Blumenau. Dentre seus artigos, destaca-se a instituição da obrigatoriedade de escovação dentária diária supervisionada, com dentifrício fluoretado, para todas as crianças que freqüentam as unidades pré-escolares e unidades de ensino fundamental, de $1^{\mathrm{a}}$ a $4^{\mathrm{a}}$ série da Rede Municipal de Ensino, durante o período letivo, a partir do ano de 1992, e também a divisão de responsabilidades entre as secretarias de educação e saúde, contemplando um planejamento educacional e preventivo nas ações de saúde bucal coletiva.

No Brasil, o programa BRASIL SORRIDENTE ${ }^{9}, 2004$, é uma política de diretrizes para a saúde bucal, a qual passa a ser uma das prioridades do governo federal, as condições da saúde bucal dos brasileiros. Dentre muitas metas, esta a preocupação com a saúde bucal dos escolares.

As políticas de saúde implementadas em escolas, como a disponibilidade de espaços para a prática de higiene bucal, capacitação dos professores em relação ao conhecimento de saúde bucal fazem parte de estratégias de Promoção de Saúde Bucal. Assim, programas educativos preventivos podem ser desenvolvidos para grupos específicos da população em ações coletivas locais em prol da saúde bucal (MOYSÉS; WATT ${ }^{36}, 2000$ ).

Com relação a grupos populacionais classificados por faixa etária, nos países onde a cárie dentária ainda representa o dano de maior amplitude populacional, tem - se priorizado as crianças em idade escolar, de 6 a 14 anos. Esta escolha deve-se ao fato de coincidir esta fase com a erupção dos dentes permanentes e pela maior incidência de cárie no período pós-eruptivo. Além disso, a facilidade de acesso nas escolas também contribui para a prioridade dessa faixa etária $\left(\right.$ PINTO $\left.^{42}, 2000\right)$. 
No plano individual, a qualidade de vida de cada pessoa, deve ser considerada como fator importante nos níveis de saúde bucal do indivíduo. Segundo BASTOS ${ }^{6}, 1996$, trata-se de promover a aquisição de hábitos de higiene e valorizá-los. A prática da higiene deve ser realizada de forma harmoniosa, sem o sentimento de obrigatoriedade. A aquisição desses hábitos tem início na infância, destacando-se a importância da prática sistemática de condutas de higiene.

VILHENA $^{61}, 1998$, afirmou que a aprendizagem é definida como sendo a modificação do comportamento, ou a aquisição de novas respostas ou reações. Em um programa de odontologia de promoção de saúde para escolas, a motivação é importante para se obter resultados significativos em educação em saúde, pois a criança aprende em grupo e com o grupo. Além disso, a motivação do escolar contagia pais e responsáveis, levando as informações necessárias para se obter e manter bons hábitos, sendo que o conhecimento assimilado durante o programa será levado por toda a vida (figura 1).

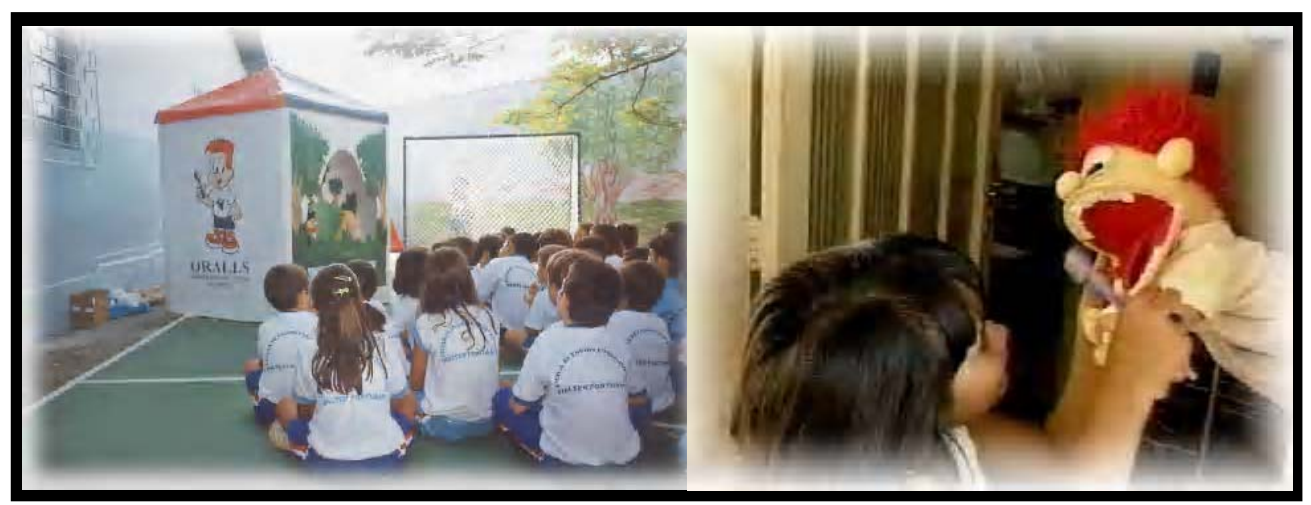

Figura 1 - Ações educativas do Programa Oralls de Odontologia Escolar.

Em 1996, NAVARRO ${ }^{38}$ et al., estudaram a variação dos índices de placa bacteriana de escolares em decorrência da aplicação de aulas educativas de 
motivação e de um método preventivo de escovação supervisionada. Em cada visita à escola durante 4 meses, foram ministradas palestras educativas sobre higiene bucal, com demonstração da técnica de escovação e evidenciação da placa bacteriana; posteriormente, os estudantes realizaram a escovação supervisionada. Os autores concluíram que houve redução de 55,4\% nos índices de placa dos estudantes selecionados, comprovando que os programas preventivos realizados em escolas são capazes de motivar e orientar os alunos quanto à prática dos hábitos de higiene bucal, obtendo resultados satisfatórios.

GOSUEN $^{23}, 1997$, determinou em uma pesquisa que os recursos utilizados para a prática de atividades educativas preventivas devam estimular as crianças no aprendizado da boa higiene bucal.

CONRADO $^{13}$ et al., 1997, criticaram os programas de motivação desenvolvidos na maioria das escolas por serem condensados e de curta duração. Dessa maneira, os programas e atividades nessa área devem ser intersetoriais e multidisciplinares com utilização de materiais que sejam atraentes, eficazes, duráveis e de fácil utilização. Para os autores, a educação em grupo tem maior poder multiplicador que o processo individual e o sucesso de um programa de motivação em educação depende da habilidade e interesse do educador.

O sucesso de um programa odontológico se deve ao impacto na execução de ações preventivas com ênfase na educação de hábitos de higiene bucal. $\mathrm{GARCIA}^{20}$ et al., 1998, verificaram que a importância no sucesso de programas é dada ao binômio prevenção - educação, sendo que devem ser realizados periodicamente.

PEIXOTO; BASTOS ${ }^{40}, 1998$, idealizaram um programa odontológico educativo preventivo no município de Luiz Antonio/SP. Tal programa era 
composto por ações preventivas como bochechos semanais com solução de $\mathrm{F}$ a 0,2\% e escovação supervisionada com dentifrício fluoretado. O programa educativo contou com palestras para os pais, escolares e funcionários, além de apresentação peças coreografias e mostra de desenhos sobre prevenção.

Com o objetivo de avaliar a eficácia da metodologia de um programa educativo - preventivo com escolares de 6 e 7 anos, SILVEIRA ${ }^{53}$ et al., 1998, compararam dois grupos de crianças de uma escola pública de Florianópolis, sendo um controle (17 alunos) e o outro experimental( 23 alunos). O estudo foi desenvolvido em um período de 11 semanas, sendo que os 2 grupos receberam as orientações de manutenção da higiene bucal nas 2 primeiras semanas e foi anotado o índice de placa. Da segunda semana em diante, o grupo experimental recebia as orientações educativas preventivas de reforço da $3^{\mathrm{a}}$ a $11^{\mathrm{a}}$ semana, e o grupo controle não. Todas as semanas foram medidos os índices de placa. Percebeu-se que a metodologia para um programa odontológico escolar foi eficaz, uma vez que houve diferença estatisticamente significante entre os índices de higiene bucal levantados para os 2 grupos favorecendo o grupo experimental.

GOMES FILHO ${ }^{22}$ et al., 1999, avaliaram um programa preventivo de saúde bucal em pré-escolares no qual foi priorizado um método de interação entre os recursos educativos (recursos audiovisuais, palestras e atividades educativas) e preventivos (escovação supervisionada e aplicações de flúor). Participaram deste estudo 127 crianças na faixa etária 4 a 6 anos divididos em grupo controle (não participavam das ações) e grupo experimental. Antes do início do programa, foi realizada a análise do índice de placa dos escolares. Após 10 meses de trabalho foi analisado novamente o índice de placa. Os autores consideraram que devido ao envolvimento do grupo experimental no programa, este grupo teve menor 
índice de placa do que o grupo controle. Além disso, a influência da motivação na melhoria da saúde bucal foi comprovada através da mudança na técnica da remoção de placa bacteriana.

ROSSETTI ${ }^{46}, 1999$, relatou em seu livro, Saúde para a Odontologia, um caso clínico de uma criança com necessidades especiais que precisava de tratamento odontológico. Segundo o autor, outros profissionais ressaltavam a importância do tratamento da criança sob anestesia geral, pois todos os molares decíduos se encontravam com hiperplasia pulpar. Porém o procedimento tomado por Rossetti foi de apenas orientar a criança e a mãe sobre a importância da escovação dentária, sendo acompanhado constantemente o nível de placa através de retornos periódicos. O resultado foi surpreendente, haja vista que nenhum procedimento invasivo aconteceu, e todos os procedimentos educativos e preventivos foram realizados com a criança no seu estado lúcido, onde depois de 5 anos de trabalho, e trocados os dentes decíduos pelos permanentes, a criança estava com todos dentes sadios.

RAMONA; PETRY ${ }^{45}$, 2002, avaliaram a eficácia de duas estratégias motivacionais em relação ao controle do biofilme dental e sangramento gengival. Participaram deste estudo 135 escolares da rede estadual e municipal de ensino do município de Santa Tereza, RS. O programa de motivação a que os escolares tinham acesso constou da utilização de diversos recursos aplicados em dois grupos de intervenção: Grupo A, motivação em sessão única, e Grupo B, motivação em quatro sessões. Para a avaliação da metodologia empregada foram realizados levantamentos do índice de placa visível (IPV), e do índice de sangramento gengival (ISG). Em ambos os grupos houve redução tanto do ISG quanto do IPV após as sessões de intervenção $(p<0,001)$. Quando comparados 
entre os grupos, o ISG, e mais marcadamente o IPV, apresentaram redução altamente significativa no grupo de intervenção $B$ quando comparado ao A $(p<0,001)$. Em conclusão, os reforços motivacionais em programas educativopreventivos atuam positivamente para a redução do biofilme dental e sangramento gengival.

Com o objetivo de avaliar a capacidade de aprendizagem de pré-escolares quanto às técnicas de escovação, $\mathrm{LEAL}^{29}$ et al, 2002, utilizaram três diferentes métodos de instrução e reforço, em uma creche de Brasília, DF. Quarenta crianças foram divididas por faixa etária em dois grupos de 3 e 4 anos de idade e 5 e 6 anos de idade, respectivamente. Foram aplicados os seguintes métodos de instrução e reforço:

I - audiovisual

II - criança como modelo

III - instrução individual

Após a aplicação de cada um dos métodos foi realizada profilaxia profissional e aguardou-se 48 horas sem que qualquer procedimento de higienização fosse efetuado. Foram realizados evidenciação de placa e o registro do índice de placa. As crianças fizeram a escovação de acordo com o que aprenderam através do método de instrução aplicado anteriormente e feito novo registro do índice de placa. Depois da aplicação de todos os métodos houve redução do índice de placa para os dois grupos, sendo que, o método de instrução individual foi o que apresentou melhor resultado.

Em um estudo realizado por CHAVES; VIEIRA -DA -SILVA ${ }^{12}, 2002$, verificou - se que as maiores reduções de cárie foram encontradas nos estudos que utilizaram escovação supervisionada através de um programa escolar 
juntamente com a escovação em casa, o que fortalece a hipótese segundo a qual as práticas educativas e de escovação supervisionada atuariam como potencializadoras da ação anti-cárie do dentifrício fluoretado. Além disso, educação em saúde, ferramenta básica e ação primária fundamental, estão sendo pouco enfatizadas ou descritas.

VILHENA $^{64}, 2003$, destacou a importância de ferramentas lúdicas em programas odontológicos educativos preventivos. Através da Turma do Escovinha $^{63}$ (figura 2), personagens infantis utilizados no programa Oralls de odontologia escolar ${ }^{62}$ (figura 1 ), os profissionais de saúde que trabalham nas atividades educativas com os escolares, conseguiram a atenção das crianças, motivando os escolares na prática de bons hábitos de saúde bucal.

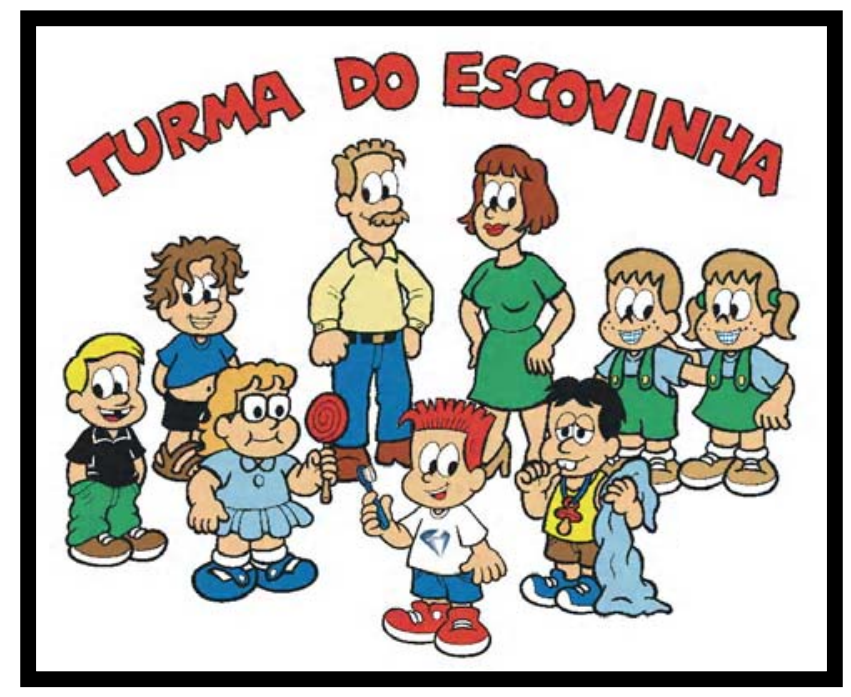

Figura 2 - Personagens lúdicos usados em programas odontológicos educativos preventivos.

VANOBBERGEN $^{60}$ et al., 2004, realizaram um estudo com a finalidade de medir o grau de aprendizado de escolares durante a aplicação de um programa educativo preventivo por um período de 6 anos. Foram utilizadas 3291 crianças com uma idade média de 7 anos no início do experimento como grupo experimental. Cada ano estas crianças eram examinadas e os pais respondiam a um a um questionário, o qual relatava os hábitos de higiene oral do escolar. Como 
grupo controle foi utilizado uma amostra de 676 escolares de 12 anos. O grupo experimental e também os professores receberam orientação sobre os cuidados com a higiene bucal durante 1 hora/ano. O efeito do programa foi avaliado medindo diferenças na prevalência e na incidência da cárie e os níveis do cuidado dental. Os índices de placa embora mais altos no grupo controle, não foram significativamente diferentes. A freqüência relatada de escovar foi a mesma em ambos os grupos. As diferenças significativas no preenchimento do questionário a favor do grupo experimental foram encontradas no número de "lanchinhos" entre as refeições $(P<0,001)$ e do uso apropriado de fluoretos tópicos $(P<0,05)$. As crianças no grupo controle mostraram uma proporção significativamente mais baixa de dentes restaurados do que aquelas no grupo experimental $(P<0,01)$, com um índice do cuidado de $73 \%$ contra $80 \%$, sendo que o CPOD foi muito baixo $(0,70)$.Os autores concluíram que um programa mínimo de instrução de saúde não resultou em uma redução significativa da prevalência de cárie medido, porém foi eficaz em melhorar hábitos dietéticos e o uso apropriado de fluoretos tópicos e resultou em um índice mais elevado de cuidados com a saúde bucal.

\subsection{Dentifrício / Flúor}

\subsubsection{Considerações Gerais}

Dentifrício é qualquer preparação usada para higienização dental, sendo que geralmente contêm abrasivo, detergente, aglutinante e um agente flavorizante, podendo existir na forma líquida, pasta, gel ou pó. Podem conter 
também medicamentos preventivos contra cáries e outras doenças bucais. (BASTOS; LOPES 5 , 2001).

BASTOS; LOPES ${ }^{5}, 2001$, relataram que a história dos dentifrícios é muito antiga. No século 5 uma prescrição comum para halitose era composta de uma mistura de cinzas de cabeça de coelho, três ratos e igual quantidade de pó de mármore misturados com água. Relatam também uma outra formulação de dentifrício formada por pedra pomes, cascas de ovos torrados, chifres de veado, camundongos e lagartos. Esta prescrição era usada pelos romanos.

Os dentifrícios foram introduzidos inicialmente no mercado de vendas como cosméticos, pois somente existia a preocupação da incorporação de agentes que melhorassem a limpeza e diminuíssem a abrasividade. Depois é que vieram os dentifrícios terapêuticos (BASTOS; LOPES 5 , 2001, CURY ${ }^{16}, 2002$, OLIVEIRA et $\mathrm{al}^{39}$. 2001, SILVA ${ }^{51}, 2000$, NARVAl $\left.^{37}, 2000\right)$.

A formulação terapêutica (preventiva) ganhou força após os anos 60, onde até então os dentifrícios tinham papel meramente cosmético (NARVAl ${ }^{37}, 2000$ ).

Este efeito terapêutico tem tido um papel importante, particularmente no controle do desenvolvimento da cárie dentária, o qual se deve `a adição do flúor, que como já se sabe, é o responsável pela diminuição da doença (CURY ${ }^{16}, 2002$, SILVA $^{51}, 2000$, CURY; VILLENA $\left.{ }^{14}, 1998\right)$.

O flúor dos dentifrícios tem capacidade de interferir na iniciação e progressão da lesão de cárie e assim manter o equilíbrio mineral dos dentes. Ele também é capaz de repor perdas minerais que já ocorreram no tecido. Quando se escova com dentifrício não fluoretado, um efeito de aproximadamente $50 \%$ na mineralização é obtido, o qual nada mais é do que a capacidade da saliva de repor mineral. Contudo, quando se utiliza o dentifrício fluoretado, a capacidade da 
mineralização da saliva é ativada pelo flúor, ocorrendo uma reposição de $90 \%$. Dessa maneira, a eficácia promovida pelos dentifrícios fluoretados é promovida por dois fatores: (1) efeito de limpeza, através da escovação e remoção da placa bacteriana, diminuindo seu potencial patogênico permitindo a ação da saliva; (2) efeito do flúor do dentifrício incrementando os efeitos remineralizantes. Muitos resultados clínicos observados nos últimos anos têm demonstrado o potencial preventivo dos dentifrícios fluoretados, proporcionando reduções de 25 a 40\% na prevalência de cárie dentária, sendo compatível com a fluoretação da água e podendo, portanto, ser utilizado concomitantemente (NARVAI ${ }^{37}, 2000$, VILLENA; CURY $^{14}, 1998$, CURY $\left.^{15}, 2001\right)$

Uma evidência da importância dos dentifrícios fluoretados como medida de saúde pública aconteceu na Inglaterra, onde menos de 10\% da população tinha acesso a água fluoretada. ALLE; ASHLEY; NAYLOR², 1983, confirmaram que o declínio da prevalência de cáries coincidiu com o aumento do uso de dentifrícios fluoretados.

LOPES; MORITA ${ }^{31}, 1997$, constataram que o efeito anti - cariogênico do flúor está relacionado à presença do mesmo nos fluídos orais, mesmo em concentrações relativamente baixas. Durante o ato de escovar os dentes com dentifrícios fluoretados, o flúor é oferecido à cavidade bucal à semelhança de uma aplicação tópica, porém em baixa concentração. Após a utilização de dentifrícios, grande parte do flúor sofre uma diluição, se perde na saliva e posteriormente deglutido, entretanto, pequenas quantidades de flúor podem ficar retidas e serem liberadas posteriormente.

TEN CATE ${ }^{58}, 1997$, realizou uma revisão sobre flúor com ênfase na prevenção de cáries dentárias através do fluoreto de cálcio. Segundo o autor, as 
baixas concentrações de flúor beneficiam a remineralização do esmalte e da dentina. Este efeito benéfico sobre a desmineralização é efetivo, pois em momentos entre as escovações e a diminuição salivar, o flúor depositado é liberado lentamente.

CURY ${ }^{15}, 2001$, relata que, os dentifrícios fluoretados são considerados a forma mais racional de uso tópico de $\mathrm{F}^{-}$, complementando as deficiências mecânicas da escovação e estabelecendo um controle físico-químico da cárie dentária.

\subsubsection{Composição dos Dentifrícios}

O composto monofluorfosfato (MFP) tem sido utilizado amplamente nas formulações de dentifrícios, principalmente devido a sua compatibilidade com os abrasivos contendo cálcio como fosfatodicálcio diidratado (DCPD) e o carbonato de cálcio $\left(\mathrm{CaCO}_{3}\right)$, permitindo que maior quantidade de flúor solúvel ("ativo") se mantenha no produto. Assim, surgiu a hipótese de que o cálcio dos sistemas abrasivos poderia exercer um efeito aditivo no MFP de dentifrícios. KOO; CURY ${ }^{25}$, 1999, analisaram a efetividade de um dentifrício "in situ" com monofluorfosfato (MFP) e sistema abrasivo fosfodicálcio diidratado (DCPD), não apenas em termos de incorporação do flúor, mas principalmente com relação a sua capacidade de remineralizar o esmalte dental humano. Os autores usaram 2 dentifrícios, um experimental o Colgate MFP com Cálcio (MFP/DCPD) tendo como abrasivo o fosfodicálcio diidratado (DCPD), e um placebo de flúor e cálcio tendo como abrasivo a sílica. Estes dentifrícios foram embalados em bisnagas identificadas por códigos de análise. Assim, o estudo foi de cego a duplo-cego quanto às 
análises. O estudo foi do tipo cross-over com oito voluntários em duas etapas de 45 dias. Os voluntários utilizaram dispositivo intra-oral palatino de resina acrílica contendo 4 blocos de esmalte com lesão de cárie artificial. Após cada etapa, foi analisada a incorporação de flúor (flúor total em ppm F) e microdureza (em Knoop) dos blocos de esmalte dental. Os resultados demonstraram que nas áreas integradas sob as curvas a concentração de flúor incorporado no esmalte tratado com dentifrício MFP/DCPD foi significativamente maior que no placebo (4.508,55 965,82 e 1.485,51 - 191, 72, respectivamente) e os dados de microdureza demonstraram que o dentifrício MFP/DCPD foi capaz de remineralizar o esmalte dental em 34\%, enquanto no placebo observou-se perda de $14 \%$ de mineral. Dessa maneira, este estudo demonstrou que o dentifrício MFP/DCPD foi efetivo não apenas na incorporação de flúor no esmalte, mas também na capacidade de remineralizar a lesão de cárie, quando comparado com o placebo.

No Brasil, a portaria $n^{\circ} 22$, de 20 de dezembro de 1989 estabeleceu normas que regulamentam a incorporação de flúor nos dentifrícios (sem obrigatoriedade), estabelecendo uma concentração mínima de 1000 e máxima de 1500 ppm de F solúvel no momento da fabricação, um mínimo de 600 ppm de F solúvel após um ano desta data e um mínimo de 450 ppm de F pelo restante do prazo de validade (BRASIL. Ministério da Saúde $\left.{ }^{8}, 1989\right)$.

Um estudo realizado por DUARTE; PISANESCHI; CURY ${ }^{17}$ em 1999, analisou - se o flúor total solúvel de 5 dentifrícios que correspondem a 92\% do total vendido no Brasil. Foram adquiridas 141 bisnagas nas cinco regiões brasileiras, e verificou - se a quantidade de flúor remanescente após um estudo de envelhecimento precoce (16 dias a $55^{\circ} \mathrm{C}$ ) em laboratório. Os resultados mostraram que os dentifrícios estão de acordo com as normas brasileiras e que, 
apesar de haver diferença na concentração de flúor em três regiões estas não são de magnitude que possa resultar em menor eficácia no controle da cárie dentária.

De uma forma geral os agentes mais comumente incorporados aos dentifrícios são o fluoreto de sódio e o monofluorfosfato de sódio. A eficácia comparativa dos dois vem sendo debatida por especialistas e pelas empresas produtoras ao longo dos últimos anos. O consenso predominante até meados da década de 80 foi de que havia superioridade para o monofluorfosfato, no qual após uma revisão, constatou-se um melhor desempenho para o fluoreto de sódio da ordem de $6,4 \%$ com base em resultados obtidos após dois a três anos de escovação continuada. Ainda assim, uma análise comparativa discutida em simpósio internacional específico realizada em Londres em 1993, concluiu que em concentrações similares não há diferença entre monofluorfosfato de sódio e o fluoreto de sódio em termos de proteção contra a cárie. A combinação de ambos num mesmo dentifrício tem sido experimentada, e tem-se obtido resultados positivos. (PINTO $\left.{ }^{42}, 2000\right)$

Através de uma pesquisa de meta-análise, CHAVES; VIEIRA - DA SILVA $^{12}, 2002$, avaliaram a efetividade da escovação com dentifrício fluoretado na redução da cárie dentária para calcular o efeito das diferentes hipóteses testadas. Foram analisados 36 estudos aprovados de acordo com os critérios estabelecidos pelos autores, sendo que 22 deles atingiram 13 ou mais dos critérios de rigor metodológico. Neste estudo, entre outros aspectos, foram comparados dentifrícios com diferentes concentrações $(250,1.000,1.500,2.500,2.800$ ppm de flúor) e com diferentes princípios ativos, sendo que houve uma predominância de investigações comparando dentifrícios a base de fluoreto de sódio com aquelas a base de monofluorfosfato de sódio. Esses estudos foram divididos em dois 
grupos: aqueles com concentrações em torno de 1.000 a 1.500 ppm e um segundo grupo independente das concentrações.

Observou-se que não houve diferenças de efeito entre os dois princípios ativos para o grupo 1.000-1.500 ppm. A escovação com dentifrício fluoretado foi responsável por uma redução de cárie de $29,1 \%$ quando comparada com o dentifrício sem flúor. Embora o aumento da concentração do flúor pareça estar associado com o aumento do efeito, com $17 \%$ de redução global para o grupo com maiores concentrações, seria pouco recomendável essa indicação, haja vista a grande preocupação com o excesso de ingestão do flúor por crianças, tendo em vista a sua associação com a fluorose. Dentifrícios fluoretados com concentrações superiores a 1.500 ppm têm sido contra-indicados.

TERDPHONG - TRIRATANA ${ }^{59}$ et al., em 2002, realizaram um estudo para determinar se um dentifrício fluoretado na forma líquida era eficaz no controle da placa e da gengivite. Foi conduzido um estudo clínico de seis meses, de acordo com o guia de procedimentos preconizados pela American Dental Association para a avaliação clínica de produtos contra a placa e gengivite. Foram utilizados 124 adultos (homens e mulheres) na faixa etária de 20 a 60 anos que não utilizaram aparelho ortodôntico e próteses removíveis, não tivessem doença periodontal avançada, não estivessem utilizando antibiótico e tivessem um escore 1,5 ou maior no exame de baseline utilizando o índice Quingley-Hein modificado para placa) e escore 1 ou maior no exame de medição da gengivite no índice Loe-Silness modificado para gengivite. Foram divididos em 2 grupos, sendo que 0 grupo experimental utilizou um dentifrício com $0,3 \%$ de triclosan, $2 \%$ de um copolímero e $0,243 \%$ de NaF e sílica, o Colgate Total (líquido), e o grupo placebo utilizou um dentifrício líquido com $0,243 \%$ de $\mathrm{NaF}$ e sílica. Os resultados do 
estudo indicaram que o uso do dentifrício líquido experimental forneceu uma redução significativa em níveis existentes de placa e da gengivite em comparação ao dentifrício placebo. Em seis meses, o grupo experimental demonstrou uma redução de 34,9 \% na formação da placa e uma redução de 25,7\% na gengivite em comparação ao grupo do placebo. Quando comparado com o placebo, o dentifrício experimental foi significativamente melhor na redução da placa e a gengivite. E ainda quando comparado com os resultados relatados na literatura, esta nova fórmula líquida de dentifrício é superior àquelas de pastas tradicionais, sendo que as implicações clínicas confirmam a eficácia do dentifrício líquido que contém a dosagem necessária de triclosan/copolymer/NaF para a redução da placa e gengivite existentes.

PUPPIN-RONTANI; CORREA-KASSAWARA; DELGADO-RODRIGUES ${ }^{43}$, 2002, desenvolveram um estudo para avaliar a influência de marca de dentifrício no nível socioeconômico e nos hábitos de escovação e a ingestão de fluoreto. Uma amostra foi obtida através de 124 crianças de 3 a 9 anos de idade, de níveis socioeconômicos diferentes, sendo que metade das crianças estudavam em escolas públicas e a outra metade em escolas particulares. Foram considerados para este estudo alguns hábitos de higiene oral como: a quantidade de dentifrício colocado, quantidade de dentifrício ingerido, quantidade de flúor ingerido e o tempo de escovação. Todas as crianças da amostra usaram 2 marcas de dentifrício, o Kolynos Super Branco com 1500 ppm de F e o creme dental Tandy uva (1100 ppm NaF ).Cada criança escovou seus dentes com ambas as marcas de dentifrício com intervalos semanais de cada dentifrício entre as escovações. Os dados obtidos foram submetidos ao teste de ANOVA. Foi observada a influência do nível sócio econômico na quantidade de dentifrício dispensado e no 
tempo de escovação (>para as crianças das escolas particulares). Em relação à marca de dentifrício houve diferença significativa, sendo que a Tandy foi maior em relação à quantidade de dentifrício colocada e menor tempo de escovação e ingestão de flúor. Os resultados mostraram uma interação significativa entre nível sócio econômico e marca de dentifrício. Embora as crianças ingerissem uma quantidade maior de dentifrício de Tandy eles ingeriram uma quantidade mais alta de fluoreto do dentifrício Kolynos Super Branco.

AMMARI; BLOCH-ZUPAN; ASHLEY ${ }^{3}$, em 2003, realizaram uma revisão sistemática com a finalidade de comparar a eficácia da prevenção de cárie dentária das pastas de dente contendo 600 ppm ou menos de $\mathrm{F}^{-}$com as pastas contendo $1000 \mathrm{ppm}$ de $\mathrm{F}^{-}$ou mais. Os resultados da meta - análise foram baseados em sete trabalhos randomizados que foram incluídos no estudo com significância estatística de $p=0.002$ e 0,0005. As pastas de dente com 250 ppm de $\mathrm{F}^{-}$não foram tão eficazes na prevenção da cárie quanto às de 1000 ppm F- ou mais. Uma outra conclusão é que mais estudos devem ser realizados para testar a eficácia dos dentifrícios anticáries de 500 até 1.000 ppm de F'.

\subsubsection{Dentifrício X Fluorose}

O estudo de HOLT et al. ${ }^{24}, 1994$, que avaliou o risco de fluorose dentária em crianças que tinham participado previamente de uma pesquisa clínica, envolvendo o efeito preventivo de cárie e o uso de dentifrícios com baixa concentração de $F^{-}$(550 ppm) na idade entre 2 de 5 anos, mostrou que as crianças que tinham usado esse dentifrício tinham uma probabilidade significantemente menor de desenvolver fluorose dentária. 
O flúor é sem dúvida alguma um grande colaborador dos profissionais de saúde bucal, pois sua possibilidade preventiva e sua utilização em larga escala beneficiou milhões de pessoas, diminuindo a severidade da doença cárie dentária, e até mesmo eliminando- a. Mas a continuidade do seu uso em ações de saúde pública necessita cada vez mais atenção, pois sem ela o risco de produção de fluorose dentária chegaria a níveis inaceitáveis. (NARVAI ${ }^{37}, 2000$, FELDENS et al. $\left.{ }^{18}, 2001\right)$

SATO; FORNAZIEIRO; WALTER ${ }^{50}$, 1997, desenvolveram uma pesquisa sobre escovação e risco de fluorose em crianças com idade variando entre 2 anos e meio a cinco anos e meio. Concluíram que para até 2 escovações/dia, utilizando dentifrícios de até 1200 ppm é seguro para as populações que moram em cidades sem flúor na água de abastecimento, mas que já apresentam problemas para aquelas que vivem em cidades com a água fluoretada e que os dentifrícios de 1450 e 1500 ppm são impróprios para uso em crianças de dois a cinco anos de idade, independente da freqüência de escovação e da existência ou não de flúor no sistema de água. Este estudo sugere que as crianças menores de cinco anos de idade usem formulações fluoretadas de concentração < 1000 ppm de $\mathrm{F}^{-}$, evitando-se assim o aparecimento de fluorose dentária.

Em 2000 a Secretaria Estadual de Saúde - SP ${ }^{49}$ publicou recomendações sobre o uso de produtos fluorados no âmbito do SUS/SP em função do risco de cárie dentária. Neste protocolo, os dentifrícios também assumem o papel nas ações coletivas como veículo para aplicações tópicas de F durante a escovação supervisionada. Esta atividade deve ser realizada no mínimo trimestralmente, em todas as pessoas, seja qual for o grupo de risco em que estejam incluídas. Ainda de acordo com estas recomendações, crianças de dois a quatro anos deglutem 
em média 50\% do dentifrício utilizado na escovação. Para crianças de cinco a sete anos, esse percentual é inferior a $25 \%$. Isto é um comprovado fator de risco para fluorose dentária.

Já de acordo como LIMA; CURY28, 2001, crianças menores de 5 anos ingerem aproximadamente $30 \%$ do dentifrício usado em cada escovação. Em acréscimo, quanto menor a idade maior a quantidade ingerida. Em um estudo realizado com crianças de 20 - 30 meses de idade residentes em áreas com água fluoretada mostrou que as mesmas atingiriam em média 0,09 mg de F/Kg/dia, tendo a dieta contribuído com $45 \%$ e o dentifrício com 55\%, deste modo excedendo a dose limite que fica entre 0,05 a 0,07 mg de F/Kg/dia. Pode-se observar a existência de um risco em potencial de se aumentar à incidência de fluorose dentária em locais onde há fluoretação das águas de abastecimento público. Os autores sugeriram dentre as alternativas para esta dose ser reduzida a utilização de dentifrício contendo 600 ppm de $F$ solúvel e utilização de no máximo 0,3 g de dentifrício por escovação.

BUZALAF et al. $^{11}$, 2002, desenvolveram um estudo transversal retrospectivo onde se associou o consumo precoce de dentifrício e outras variáveis com a fluorose dentária, através de questionários completados pelos pais, verificou - se que o início precoce da escovação com dentifrício fluoretado apresentou uma correlação positiva com a prevalência de fluorose dentária ( $p<$ 0,05). Concluiu-se que deve haver um melhor esclarecimento de pais e crianças quanto ao uso de dentifrícios fluoretados e demais fatores de risco para fluorose dentária.

ALBUQUERQUE; LIMA; SAMPAIO ${ }^{1}, 2003$, avaliaram a utilização de dentifrícios fluoretados em pré-escolares na cidade de João Pessoa - PB. A 
amostra foi composta de 296 questionários respondidos por pais ou responsáveis de crianças de 2 a 5 anos de idade de escolas públicas (168) e particulares (128). Os resultados mostram que não há diferença entre o uso de cremes dentais, infantil e adulto, nas escolas públicas, diferentemente da escola privada, onde $83,6 \%$ das crianças usam dentifrício infantil, $12,5 \%$ usam apenas o de adulto e $3,9 \%$ usam ambos os cremes dentais. Já em relação ao número de vezes de escovação, mais de $78 \%$ das crianças (públicas e privadas) escovam de 2 a 3 vezes por dia. Quanto à quantidade de dentifrício, mais de $50 \%$ dos pais de ambas as escolas assinalaram no questionário que as crianças usam uma quantidade moderada. De acordo com este estudo, as crianças estudadas iniciaram o uso de dentifrício fluoretado em idade precoce, antes do recomendando, usando uma quantidade maior do que a indicada, sendo que as maiorias das crianças usam inadequadamente o dentifrício fluoretado.

$\mathrm{Na}$ Comunidade Européia verificaram-se os riscos, prevalência e os problemas estéticos causados pela fluorose. WHELTON et al. ${ }^{69}, 2004$, observaram através de uma revisão que nas áreas com flúor na água, a idade de começar a escovar, a freqüência de escovar, a concentração do fluoreto, a quantidade de dentifrício aplicado na escova dentária, e o quanto às crianças engolem o dentifrício, foram implicadas como fatores de risco potenciais de fluorose. Nas áreas onde a água não é fluoretada, a idade de começar a escovar foi associada com o fluorose. As medidas preventivas para minimizar os fatores estéticos de risco à fluorose nos dentes anteriores incluem a supervisão da escovação por crianças abaixo de 5 anos, dispensando quantidades como um "grão de ervilha" de creme dental. 


\subsubsection{Uso Adequado do Dentifrício}

Em 1997, BENTLEY; ELLWOOD; DAVIES ${ }^{7}$ realizaram um estudo para determinar a conseqüência da quantidade de dentifrício fluoretado colocado na escova de crianças pequenas pelas mães quando treinadas para usar uma quantidade equivalente a um "grão de ervilha" ou um "pouquinho". Foram utilizados 2 dentifrícios contendo diferentes concentrações de fluoreto ( Colgate convencional 1450 ppm de F e Colgate gel infantil 400ppm de F) com diferentes formatos de aberturas do tubo ( redondo e estrela). Uma amostra de conveniência de 53 mães de crianças em idade pré-escolar foi utilizada. As mães responderam um pequeno questionário que entre outros assuntos tratava-se de:

- Idade da criança;

- O tipo de dentifrício normalmente utilizado;

- O número de vezes por dia em que a criança escova os dentes.

Os tubos de dentifrício foram mascarados para que não pudessem ser identificados. Cada mãe aplicou em uma escova pré-pesada uma quantidade de dentifrício seguindo uma seqüência que encontra - se na tabela 1.

Tabela 1 - seqüência da aplicação de dentifrícios.

\begin{tabular}{ccc}
\hline DENTIFRícIo & ABERTURA DO TUBO & INSTRUÇÃo \\
\hline Colgate gel infantil & Estrela & Grão de ervilha \\
Colgate gel infantil & Estrela & Pouquinho \\
Colgate gel infantil & Redondo & Grão de ervilha \\
Colgate gel infantil & Redondo & Pouquinho \\
Colgate convencional & Estrela & Grão de ervilha \\
Colgate convencional & Estrela & Pouquinho \\
Colgate convencional & Redondo & Grão de ervilha \\
Colgate convencional & Redondo & Pouquinho \\
\hline
\end{tabular}


O peso do dentifrício dispensado por cada mãe foi calculado através de uma balança eletrônica portátil. A média da idade das crianças foi de 2 anos e meio, e $81 \%$ das mães disseram que escovam os dentes dos seu filhos 2 vezes por dia. Setenta por cento usavam dentifrício infantil e o restante um dentifrício familiar. Não houve diferença estatística entre os bicos dos tubos de dentifrício. Quando a mãe foi orientada a colocar "um pouquinho" (0,22g em média) houve diferença estatística para o "grão de ervilha" (0,30g em média). Também ocorreu diferença estatística entre a dispensação de colgate 1450ppm de F e (0,28 g em média) e o colgate gel infantil 400 ppm de $F(0,25 \mathrm{~g}$ em média). Os resultados deste estudo sugeriram que a escolha pela instrução de usar "um pouquinho" de quantidade de dentifrício em crianças pré-escolares deve ser preferida do que o "grão de ervilha" para redução da quantidade de dentifrício aplicada. Além disso, a consistência também influencia na quantidade de dentifrício aplicado. Dessa maneira, crianças abaixo de 7 anos de idade que têm baixo risco à cárie pode-se recomendar um dentifrício com baixa concentração de flúor. Escolares com alto risco à cárie, devem usar um dentifrício que contenha quantidade convencional de flúor. Em ambos os casos é essencial que os pais supervisionem e coloquem uma pequena quantidade de dentifrícios ("grão de ervilha" ou "pouquinho") durante a escovação de seus filhos. 
Pais ou responsáveis devem ser orientados a supervisionar as escovações domésticas ou as realizadas em ações coletivas pelo menos até os sete anos de idade, para instruir as crianças a não engolirem a espuma da escovação, e para colocar na escova pequena quantidade de pasta. Além disso, recomenda-se para a faixa etária em torno dos sete anos de idade a técnica transversal de aplicação do dentifrício (figura 3), a qual consiste em posicionar o tubo de dentifrício em posição perpendicular ao longo eixo da escova, passar no centro da ponta ativa do instrumento, uma quantidade de dentifrício correspondente a, no máximo, metade da largura da ponta ativa. Essa quantidade equivale a um grão de ervilha pequena, que é suficiente para a finalidade. Para as crianças menores de quatro anos, sugere-se a "técnica da tampa", à qual consiste em, com a bisnaga fechada pressionar levemente o tubo de modo a que fique retida, na parte interna da tampa (seja ela rosquiável ou não) uma pequena quantidade de pasta. Então, abre-se o tubo e pressiona se aponta ativa da escova contra parte interna da tampa de modo a transferir para escova a pequena quantidade de pasta ali retida (figura 4) (SÃO PAULO. Secretaria Estadual de Saúde ${ }^{49}, 2000$ ).

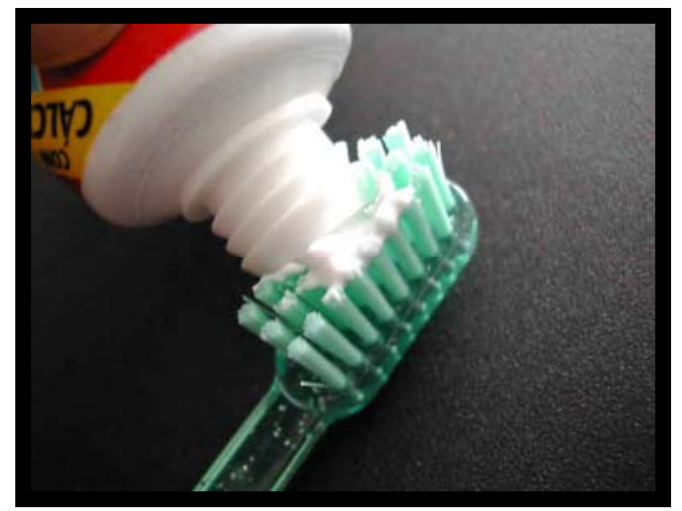

Figura 3 - Técnica transversal.

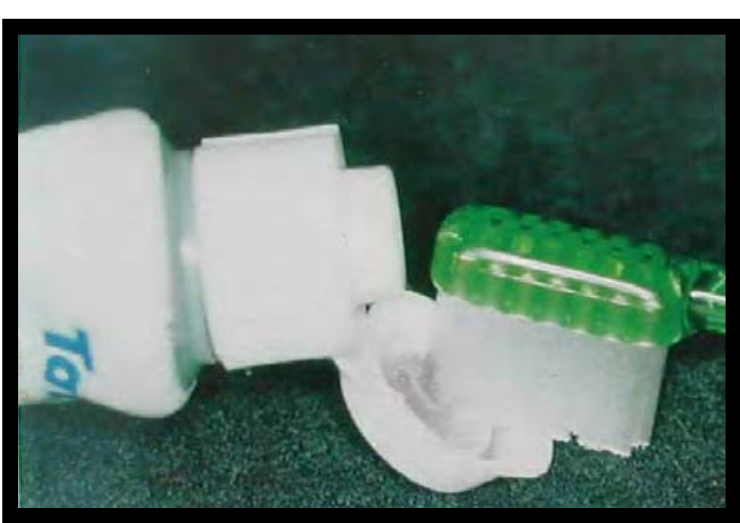

Fonte: CURY, 2002.

Sendo assim, deve ser levada em consideração a possibilidade de ingestão de flúor associada às diversas técnicas, em função da idade do grupo 
considerado, minimizando os riscos de ocorrência de fluorose dentária (SÃO PAULO. Secretaria Estadual de Saúde ${ }^{49}, 2000$, VILLENA ${ }^{66}, 2002$, CURY $\left.^{16}, 2002\right)$. FELDENS et al. ${ }^{18}, 2001$, avaliaram a utilização de dentifrício fluoretado por crianças de 2 a 5 anos de idade através de um questionário aplicado aos pais(142 participantes), em 3 escolas da cidade de Porto Alegre, 2 particulares e uma pública, $(A=33, B=20, C=89$ respectivamente $)$. Eles utilizaram as respostas desta pesquisa juntamente com os achados da literatura para se obter um referencial para encontrar possíveis fatores de risco à fluorose dentária. Os resultados mostraram que $24,5 \%$ das crianças iniciaram o uso de dentifrício entre seis meses e um ano, idade considerada muito precoce para a introdução deste hábito. Este dado quando comparado coincide com relatos da literatura de que algumas crianças são expostas precocemente ao dentifrício fluoretado, em quantidade grande o suficiente para se ter um efeito sistêmico nocivo do flúor durante a formação da dentição permanente e alguns dentes decíduos posteriores. Quanto a colocação do creme dental verificou-se que em 79,4\% das respostas obtidas indicaram os pais como os responsáveis, confirmando os achados literários, onde se encontrou que em $71,3 \%$ casos os pais colocavam o dentifrício na escova dental dos filhos. Em relação ao uso, quase $80 \%$ das crianças usavam um dentifrício infantil, sendo que $67,6 \%$ se referiram ao método transversal $(0,40 \mathrm{~g})$. Se o dentifrício utilizado for de $1100 \mathrm{ppm}$, estas crianças estarão colocando diariamente dentro da boca a quantidade de 1,2 g de dentifrício por dia, o que corresponde a 1,32 mg de flúor. Embora as quantidades deglutidas e absorvidas variem muito dependendo da idade da criança e do momento de ingestão, estes dados indicam, indubitavelmente, que as crianças avaliadas na amostra estão expostas a uma via considerável de fluorose. Os autores 
concluíram que a maioria dos pais supervisiona escovação dos filhos colocando dentifrício e auxiliando - os na técnica que é realizada de duas a três vezes ao dia. A maioria dos pais considera importante o uso do dentifrício, mas desconhece que seus filhos estão engolindo quantidades significativas de flúor diariamente, estando desta forma expostos à fluorose. O dentista deve orientar de forma mais contundente e com base científica as famílias no que se refere principalmente à idade de introdução dos dentifrícios e quantidade a ser utilizado em cada idade, a fim de diminuir uma variável importante que pode levar a fluorose dentária.

SILVA et al. $^{52}$, 2004, relataram o potencial anti - cariogênico de uma formulação de dentifrício na forma líquida (o termo "dentifrício líquido" não é um líquido igual a água, mas menos viscoso do que os géis tradicionais). Os autores compararam o Colgate Total na forma de pasta e o Colgate Total na forma líquida, e concluíram que o dentifrício líquido estudado previne 13,1\% mais lesões de cárie interproximal, do que a pasta de dente tradicional.

Ainda em relação ao dentifrício líquido, VILHENA; SALES PERES; BASTOS $^{65}, 2004$, sugeriram a utilização de um Kit Coletivo de armazenamento de escovas e dentifrício líquido como solução econômica e adequada, já que a utilização da "técnica da gota" padroniza a dose de dentifrício utilizado (figuras 5 e $6)$.

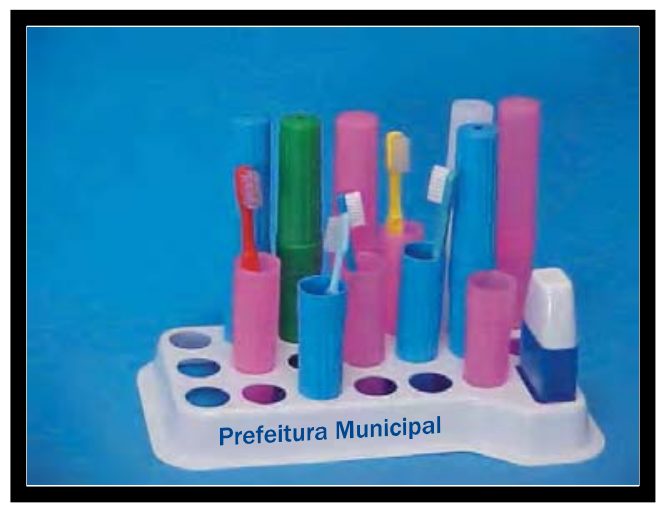

Figura 5 - Kit de armazenamento coletivo de escovas e dentifrício líquido.

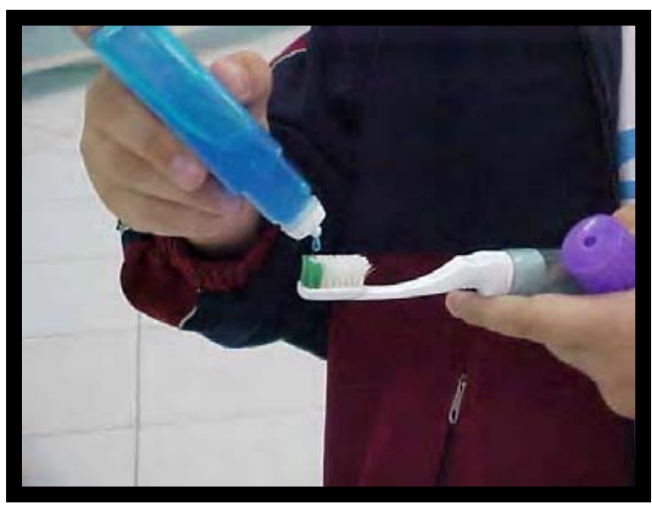

Figura 6 - Utilização do dentifrício líquido através da "técnica da gota". 


\subsection{Armazenamento de Escovas}

A higiene bucal é relacionada à diminuição da cárie dentária, saúde gengival, estética e relação social do indivíduo. As qualidades físicas das escovas dentais são fundamentais para proporcionar resultados eficazes ou não na limpeza dental. As escovas dentais devem ser limpas, secas após o uso e devidamente armazenadas, para se conservarem satisfatórias por um período razoável de tempo $\left(\mathrm{KWON}^{27}, 2000\right)$.

Tão importante quanto o uso do material de higiene bucal, através da prática da escovação dentária, é a forma de armazená-lo. Estudos realizados demonstraram a capacidade de contaminação das escovas por bactérias provenientes da microbiota bucal e outras fontes de contaminação, sendo que podem variar de acordo com cada indivíduo (SVANBERG ${ }^{56}, 1978$, TAJl; ROGERS $^{57}$, 1998) Outros trabalhos prevendo esta contaminação, estudam maneiras de como descontaminar as escovas dentais (QUIRYNEN et al. ${ }^{44}, 2003$ ).

SVANBERG ${ }^{56}, 1978$, concluiu que o número de bactérias nas escovas armazenadas em locais ventilados, após uso, decresceu num período menor de tempo do que as escovas armazenadas em recipientes fechados, e sugerem o acondicionamento em recipientes que permitam a circulação de ar e com um mínimo de contato de sua superfície com as escovas, para reduzir o contato com superfícies contaminadas.

PINTO et al. ${ }^{41}$, 1997, descobririam que as escovas dentais podem funcionar como reservatórios de microorganismos periodontopatogênicos, proporcionando a transmissão destes. Por esse motivo, é preciso esclarecer a 
população sobre as principais vias de trasmissão destes microorganismos, tal como as escovas, para prevenir que ocorra a sua contaminação.

LONG et al. $^{30}, 2000$, avaliaram a contaminação de escovas por enterobactérias. Foram analisadas 30 escovas dentárias entre 3 grupos de 10 indivíduos armazenadas no banheiro, das quais um grupo armazenava no armário, outro dentro de caixa de acrílico e ou outro em cima da pia. Após 1 mês de uso as escovas foram submetidas a análise microbiológica. Foi observado um crescimento bacteriano em $36,6 \%$ da amostra (11 escovas -7 na pia e 4 na caixa de acrílico). Os autores concluíram que apesar do pequeno número de amostras, a forma de acondicionamento do material de higiene bucal, pode interferir na presença de microorganismos, em especial as enterobactérias.

Um outro estudo semelhante foi desenvolvido por SILVEIRA et al. ${ }^{54}, 2002$, para verificar a contaminação por enterobactérias. Neste trabalho foi observada a eficiência de um porta escova simples confeccionado a partir de garrafas descartáveis de plástico utilizadas para armazenar refrigerantes. Os resultados mostraram uma menor contaminação das escovas armazenadas dentro dos porta - escovas, em relação as escovas sem porta escova. (figura 7)

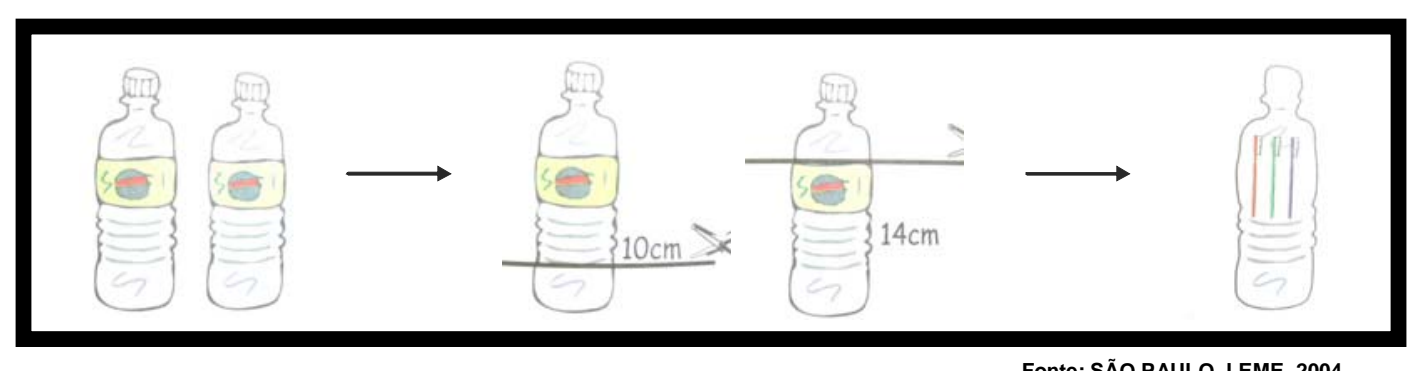

Fonte: SÃo PAULO. LEME, 2004.

Figura 7 - Desenho esquemático de confecção de porta escova coletivo.

Na prefeitura de Leme $^{48}$ os profissionais da área de saúde preocupados com a maneira de acondicionamento do material de higiene bucal da população, 
através da Secretaria Municipal de Saúde, desenvolveram uma cartilha que dentre outros assuntos traz a idealização de um porta escova muito semelhante ao preconizado por SILVEIRA et al. ${ }^{54}, 2002$. Através de 2 garrafas descartáveis de plástico, confecciona-se um porta escova simples e barato, o qual ajudará e muito na prevenção da saúde da população (figura 7).

No Rio de Janeiro, SILVEIRA et al. $.^{55}, 2000$, observaram em seis creches municipais as formas de armazenamento e manipulação das escovas dentárias, verificando as condições higiênico-sanitárias. $7 \%$ das escovas não estavam identificadas e 1\% mal identificadas (ilegíveis). Já em relação às condições de higiene, previamente à escovação, $56 \%$ apresentavam resíduos, predominantemente creme dental. Quanto ao material utilizado no porta-escovas: predominância do plástico em 35 \%, madeira 15\%, pano 15\%, papelão 11\%. Em $46 \%$ dos mesmos sua apresentação permite o contato direto das escovas entre si, $38 \%$ permitem o contato das cerdas das escovas com o porta-escovas e $73 \%$ permanecem descobertos. Quanto à manipulação das escovas e escovação observou-se: em $18 \%$ das turmas as escovas são retiradas coletivamente do porta escovas, e em 100\% das turmas a dispensação do creme dental permite 0 contato do tubo com a escova. Em $30 \%$ das turmas a educadora realiza a escovação de uma parcela das crianças, $26 \%$ apenas supervisiona, $22 \%$ realiza a escovação, $7 \%$ as crianças escovam sozinhas e em $15 \%$ não é realizada qualquer higienização bucal. Posteriormente a escovação, 20\% das turmas realizam uma lavagem coletiva das escovas, e $42 \%$ não realizam nenhuma forma de secagem das mesmas, enquanto $8 \%$ seca com uma mesma toalha de pano. De acordo com o resultado encontrado, os autores sugeriram a necessidade da 
normalização das ações de higienização bucal com a implementação de um programa de motivação e capacitação para as educadoras.

VILHENA; SALES PERES; BASTOS ${ }^{65}, 2004$, descreveram um novo kit de armazenamento coletivo de escovas e dentifrício, composto por suporte coletivo e porta escovas individuais. De acordo com os autores, o kit em questão é de grande valia nas ações coletivas de saúde bucal no Sistema Único de Saúde (SUS), uma vez que ele permite o armazenamento adequado de escovas e dentifrícios.(figuras 5 e 8) 


\section{PROPOSIÇÃO}

Este estudo visa comparar diversos métodos existentes de armazenamento de escovas e dentifrícios em ambientes coletivos (kits de higiene bucal coletiva), tendo como objetivos:

- Determinar o grau de satisfação do responsável pela higiene bucal dos escolares em relação ao KIT utilizado;

- Analisar a quantidade de dentifrício utilizada por escolares seja no uso de dentifrício na forma tradicional de pasta ou líquido;

- Propor um KIT de higiene bucal relacionando forma de armazenamento, praticidade, tipo de dentifrício, higiene e custo. 


\section{MATERIAIS E MÉTODOS}

Neste estudo foram avaliados 5 formas de acondicionamento do material de higiene bucal de escolares na faixa etária de 4 a 8 anos.

- Kit 1 - Estojo individual de plástico de $20 \mathrm{~cm}$ de comprimento, $10 \mathrm{~cm}$ de largura e $3 \mathrm{~cm}$ de profundidade, com tampa. A identificação do escolar é feita através do nome escrito na escova e na tampa do estojo. Dentifrício utilizado na forma creme dental. Tanto a escova quanto o creme dental são guardados juntos (figura 9);

- Kit 2 - Estojo coletivo feito em lona, com um dos lados liso e o outro com tecido trançado. Para evitar que as escovas dentárias permaneçam guardadas, existem casulos para guardar as escovas e o creme dental que é coletivo. Para facilitar o armazenamento, a lona permite que seja enrolada e guardada. A identificação do escolar é feita através do nome escrito na escova. ( figura 10);

- $\underline{\text { kit } 3}$ - Estojo coletivo de plástico com dimensões de $20 \mathrm{~cm}$ de comprimento, $12 \mathrm{~cm}$ de largura e 6 de profundidade com tampa, para armazenamento de escovas e dentifrícios. As escovas são identificadas através de etiqueta com nome e estão separadas individualmente por sacos plásticos do tamanho da escova. O dentifrício também é no formato de pasta ou creme dental (figura 11);

- $\underline{\text { Kit } 4}$ - Estojo coletivo feito de garrafa plástica de refrigerantes descartável, cortada a $12 \mathrm{~cm}$ do fundo, ou lata porta lápis de $10 \mathrm{~cm}$ de comprimento por $9 \mathrm{~cm}$ de diâmetro, sendo utilizada como recipiente de acondicionamento das escovas sem separação entre elas. As escovas 
são identificadas pelo nome escrito diretamente na escova, ou através de etiquetas, e o creme dental é coletivo, e é guardado juntamente com as escovas (figura 12);

- Kit 5 (experimental) - Suporte coletivo para porta-escova composto de plástico,com $25 \mathrm{~cm}$ de comprimento, $9 \mathrm{~cm}$ de largura e 3 de altura, com capacidade para armazenar 20 (vinte) porta-escovas e 01 (um) dentifrício de $100 \mathrm{~g}$. Os porta-escovas são compostos de polipropileno, com 19,5 cm de comprimento e $3 \mathrm{~cm}$ de largura, de uso individual e possui um orifício em cada extremidade que garante a circulação do ar evitando a umidade e atendendo as condições de higiene necessárias para o armazenamento de qualquer escova existente no mercado. Dentifrício na forma de gel fluido (líquido) com $100 \mathrm{~g}$ (figura 8). A identificação do escolar é feita através do nome escrito na escova e também no porta escova. Patente requerida junto ao Instituto Nacional de Propriedade Industrial (PAT. REQ. ).

\section{ETAPA I}

A primeira etapa do trabalho contou com uma amostra composta por conveniência de 20 responsáveis pela higiene bucal dos escolares, sendo 15 de 4 escolas públicas de Bauru e 5 de uma escola particular de São José dos Campos, ambos os municípios no estado de São Paulo.

Os participantes desta etapa, responderam a 2 questionários (anexo I e II) em 2 fases da seguinte forma: 
Fase 1

Os participantes (responsáveis pelos kits 1, 2 e 4 - professores e os responsáveis do kit 3 cirurgiões dentistas) responderam ao anexo I, baseando-se nos Kits de 1 à 4, isto é, 5 responsáveis por Kit. Os Após o recolhimento dos questionários foi distribuído o Kit 5 (experimental), para ser usado durante 30 dias.

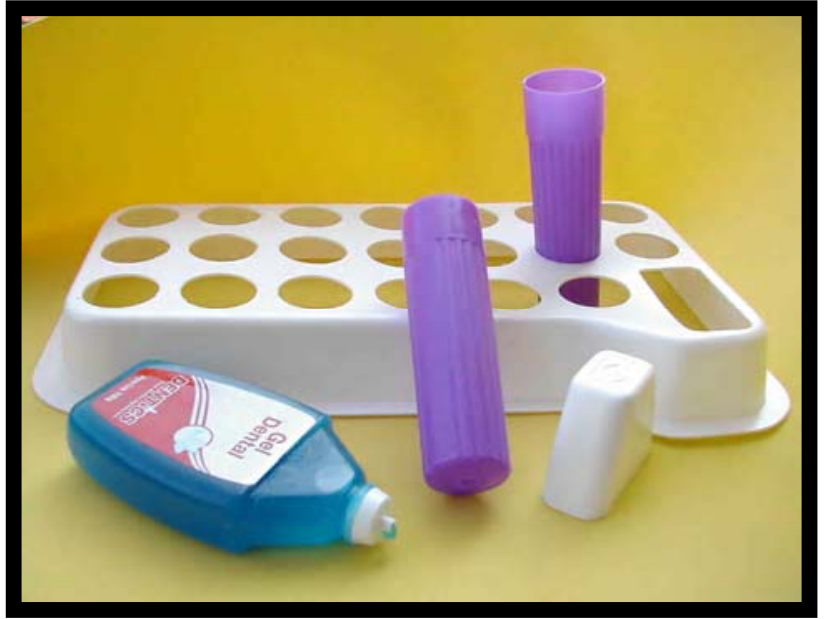

Figura 8 - Kit experimental número 5.

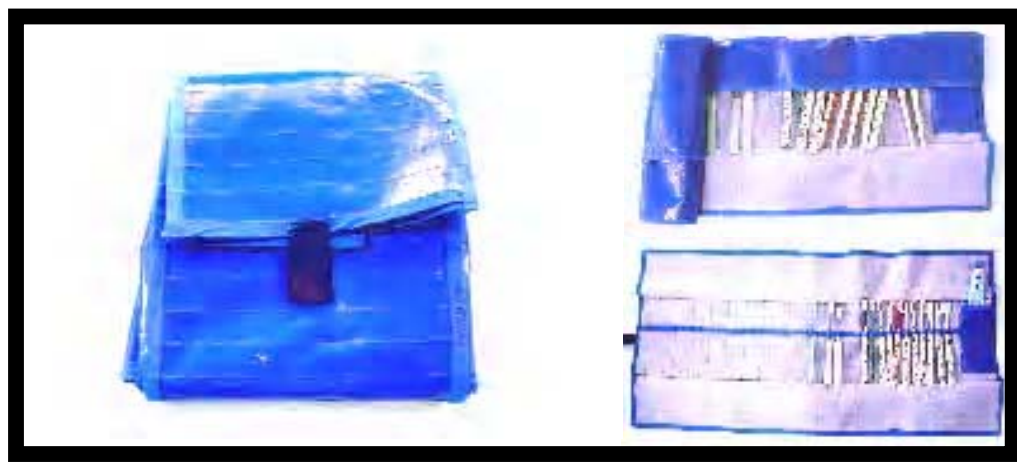

Figura 10 - Kit controle número 2.

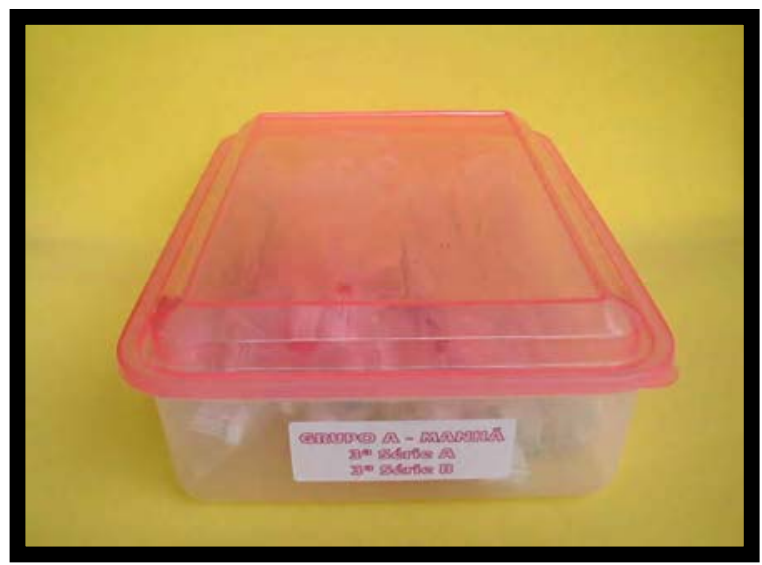

Figura 11 - Kit controle número 3.

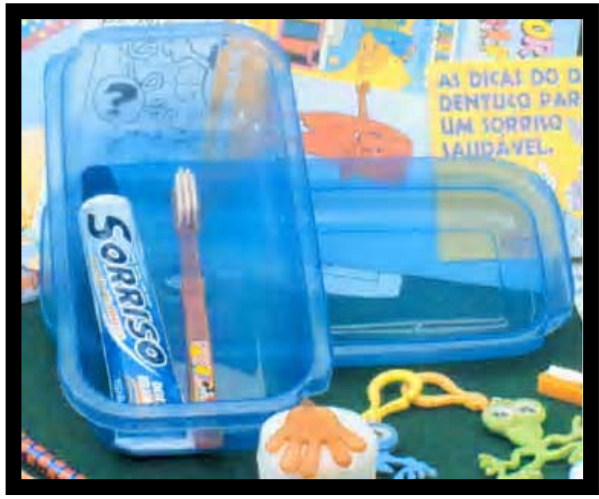

Figura 9 - Kit controle número 1.

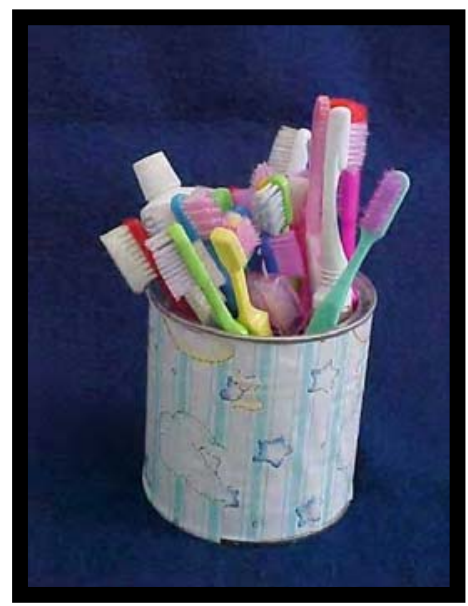

Figura 12 - Kit controle número 4.

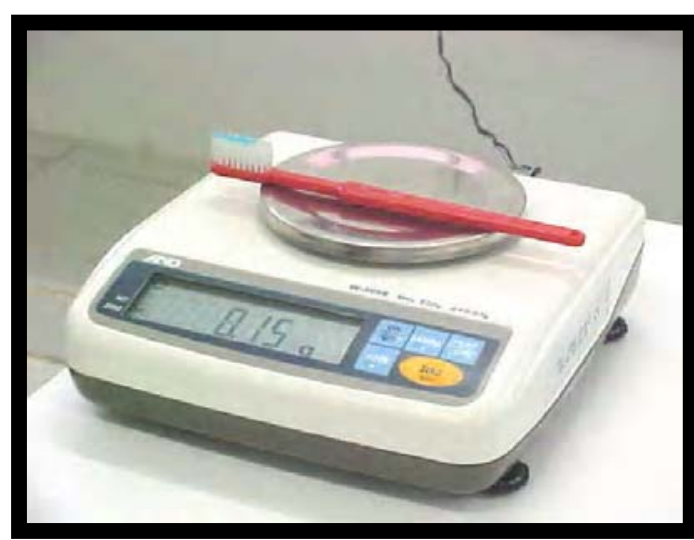

Figura 13 - Balança portátil. 
Fase 2

Decorridos 30 dias, os mesmos participantes responderam novamente 0 anexo I, porém agora em relação ao Kit 5. Depois responderam o anexo II (preferência por um dos kits, podendo marcar os 2 ).

A análise estatística desta etapa foi realizada por meio do teste Wilcoxon com significância de $p<0,05$.

\section{ETAPA II}

Este trabalho ainda contou com uma segunda etapa, a qual está descrita abaixo:

Uma outra amostra composta por crianças de 4 escolas públicas na faixa etária de 4 a 8 anos, sendo 2 na cidade de Bauru (73 escolares) e 2 na cidade de Bariri (105 escolares). Uma balança de precisão foi utilizada para a pesagem do dentifrício dispensado pelo escolar para a prática da escovação dentária (figura 13). No momento da escovação, pesava-se a escova dentária antes da colocação do dentifrício pelo escolar, tarava - se a balança com a escova em cima, e depois pesava - se novamente a escova com o dentifrício colocado. O valor da segunda pesagem era a quantidade de dentifrício colocada pelo escolar. Durante este procedimento, o escolar não recebeu nenhuma orientação sobre a maneira e a quantidade de dentifrício a ser dispensado. Depois disso, a criança recebia orientação durante a escovação.

Foram distribuídos dentifrícios na forma de pasta da marca SORRISO 90g (COLGATE PALMOLIVE - São Paulo - SP) e dentifrício na forma líquido da 
marca Dentics 100g (POLI PRODUTOS - Lorena - SP), ambos com 1100 ppm de $\mathrm{F}^{-}$.

A título de facilitar o entendimento do estudo, o termo dentifrício líquido descrito, será adotado de acordo com o proposto por SILVA et al. ${ }^{52}, 2004$, o qual não é tão líquido como a água e nem tão sólido como as pastas tradicionais. Os dentifrícios foram comprados em um distribuidor de materiais farmacêuticos. A pesagem foi realizada em triplicata, sendo encontrada uma média a qual foi utilizada neste estudo. Este procedimento ocorreu para os 2 dentifrícios.

Também através de método observacional analisou-se a forma como os escolares dispensavam as pastas de dente nas escovas.

A análise estatística foi obtida através da comparação das médias das quantidades dispensadas nas cidades e o tipo de dentifrício utilizado. 0 coeficiente de correlação de Pearson foi utilizado para verificar a correlação entre a idade e a quantidade de dentifrício dispensada. Para comparar as médias da quantidade nas cidades e o tipo de dentifrício usado, foi utilizada a Análise de Covariância (ANCOVA). Nesta comparação a idade foi usada como covariável. Os graus de significância obtidos tiveram um $p<0,05$. 


\section{RESULTADOS}

As tabelas 2, 3, 4, 5 mostram os resultados obtidos através dos anexos I e II (fases 1 e 2), sendo que o anexo I foi respondido 2 vezes, uma para o kit experimental (kit 5) e outra para o kit controle (kits de 1 à 4). Os resultados do anexo II se encontram na coluna "Kit 5 > que o Kit controle ( kits de 1 à 4)".

O teste estatístico aplicado para a comparação entre os kits foi o não paramétrico de Wilcoxon e adotado nível de significância de 5\% $(p<0,05)$.

As tabelas $6,7,8,9$, demonstram os resultados obtidos em cada quesito através das médias dos escores. Este resultado foi obtido através de todas as respostas de cada sub item de cada questão.

O escore foi a maneira encontrada de se medir através de números o grau de satisfação. Os resultados apresentados seguem a seguinte legenda:

0 - insatisfeito / 1 - pouco satisfeito / 2 - satisfeito / 3 - muito satisfeito 


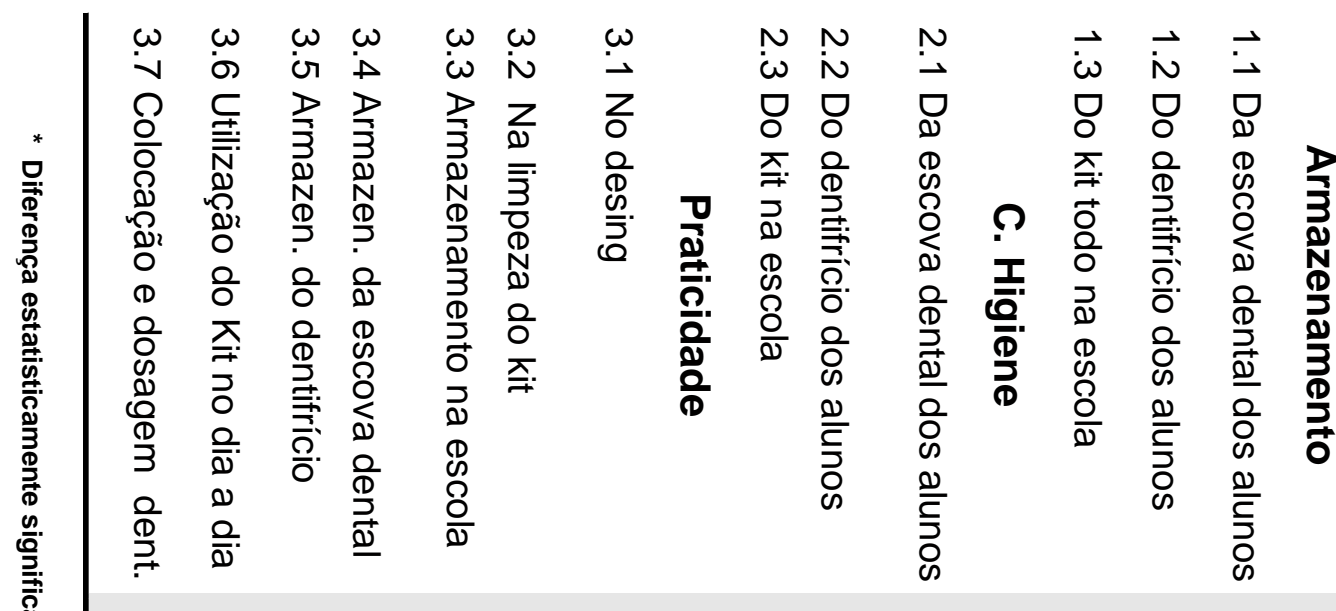

高 営 영

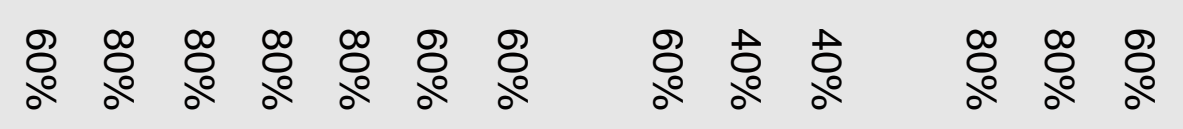

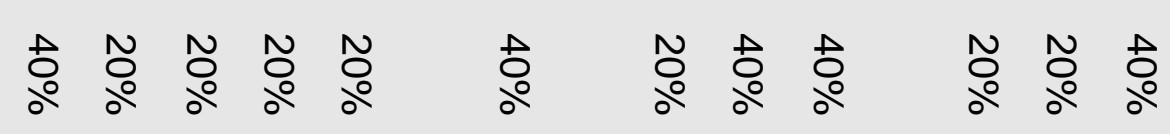
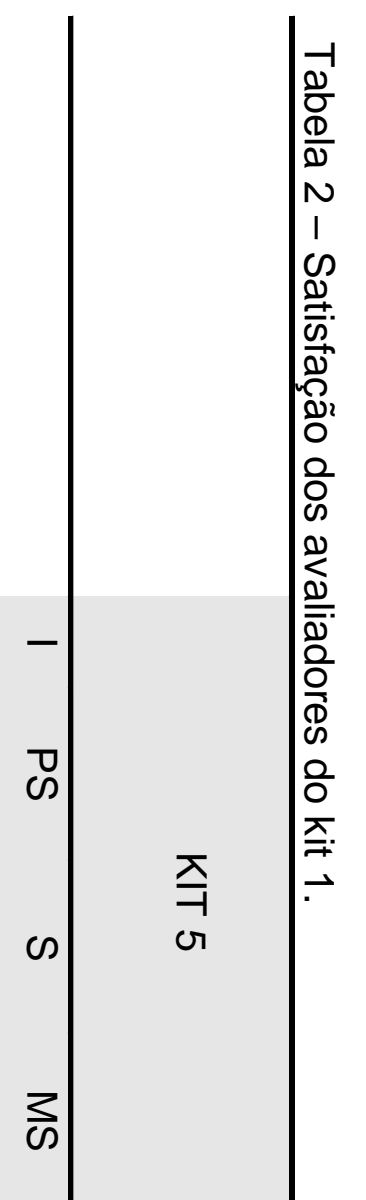

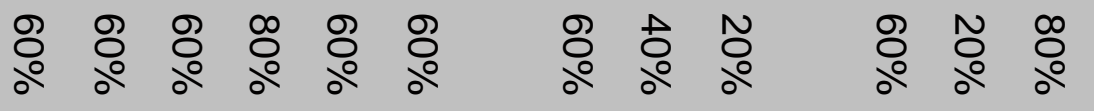

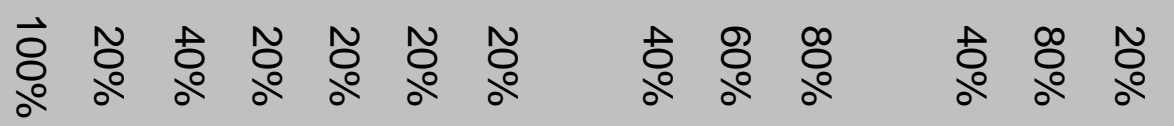

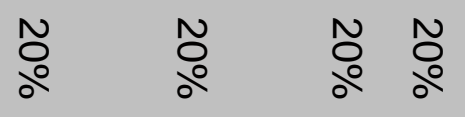

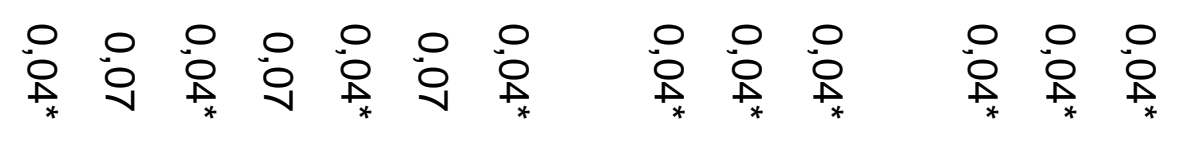

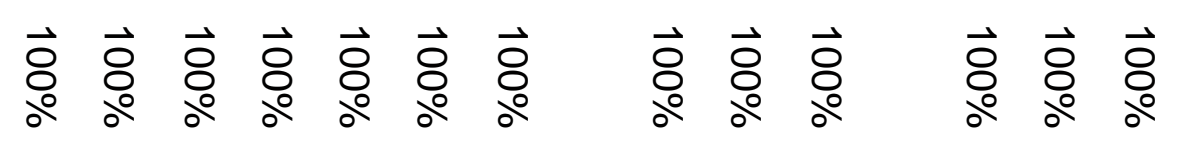

즐 중 


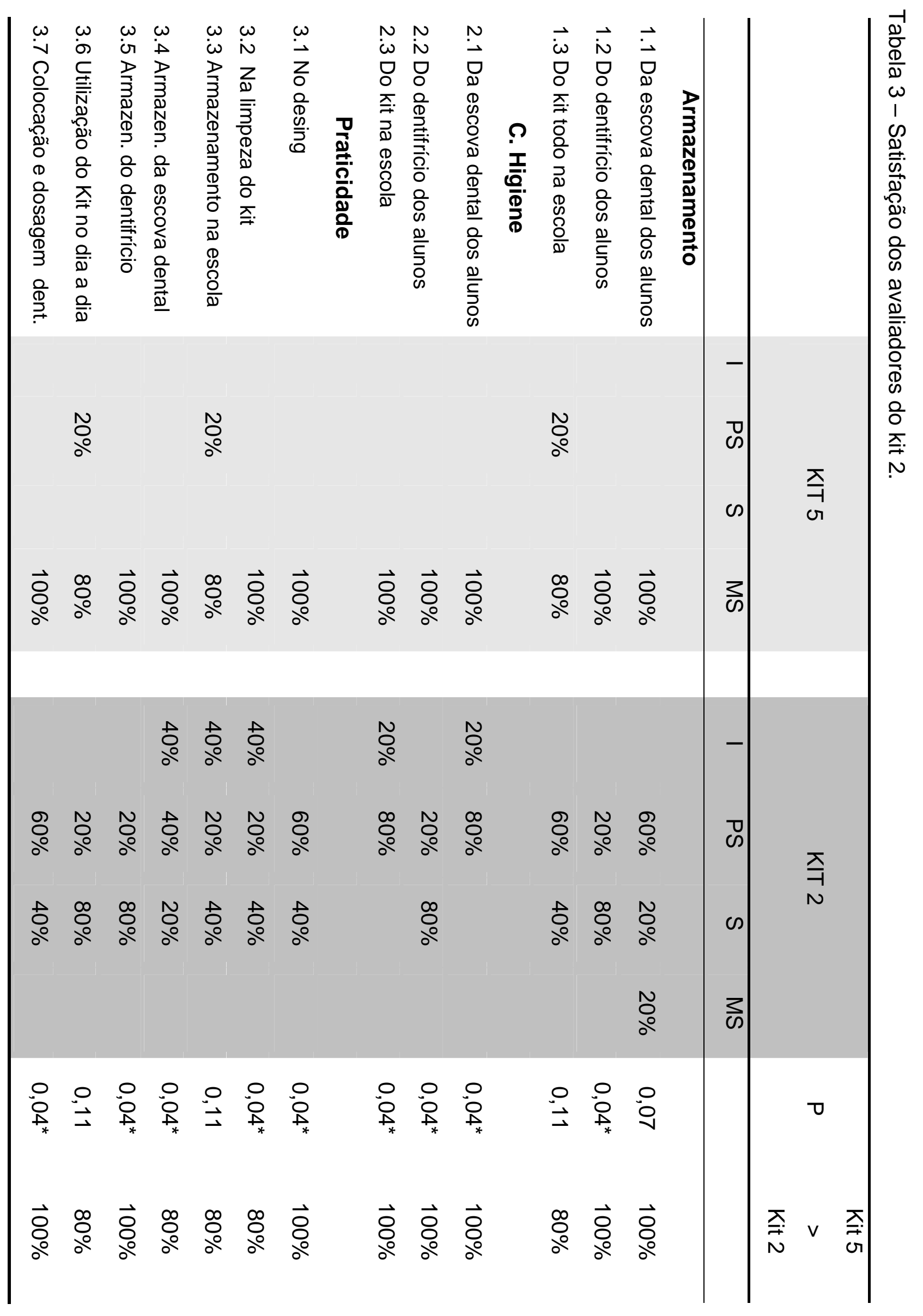




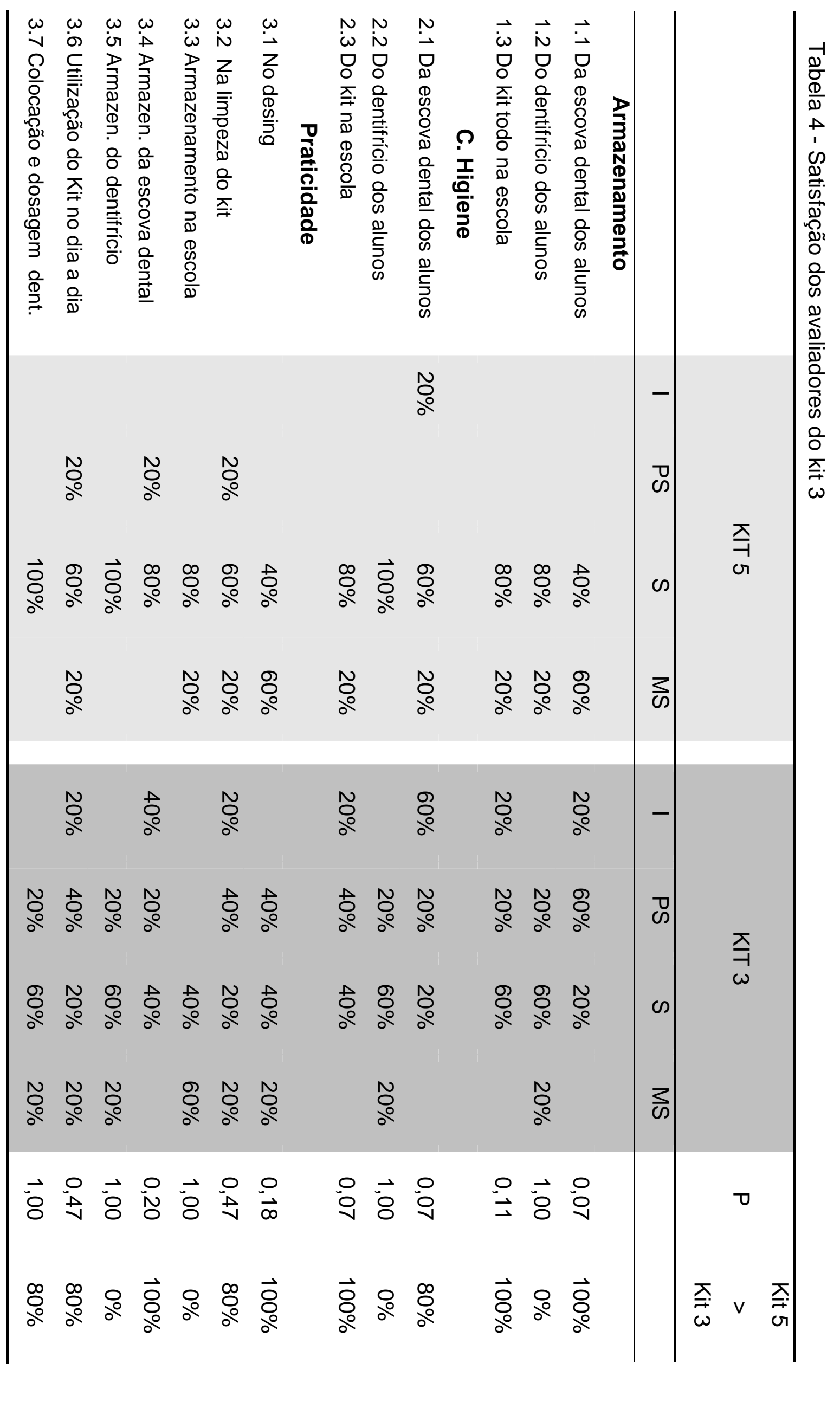




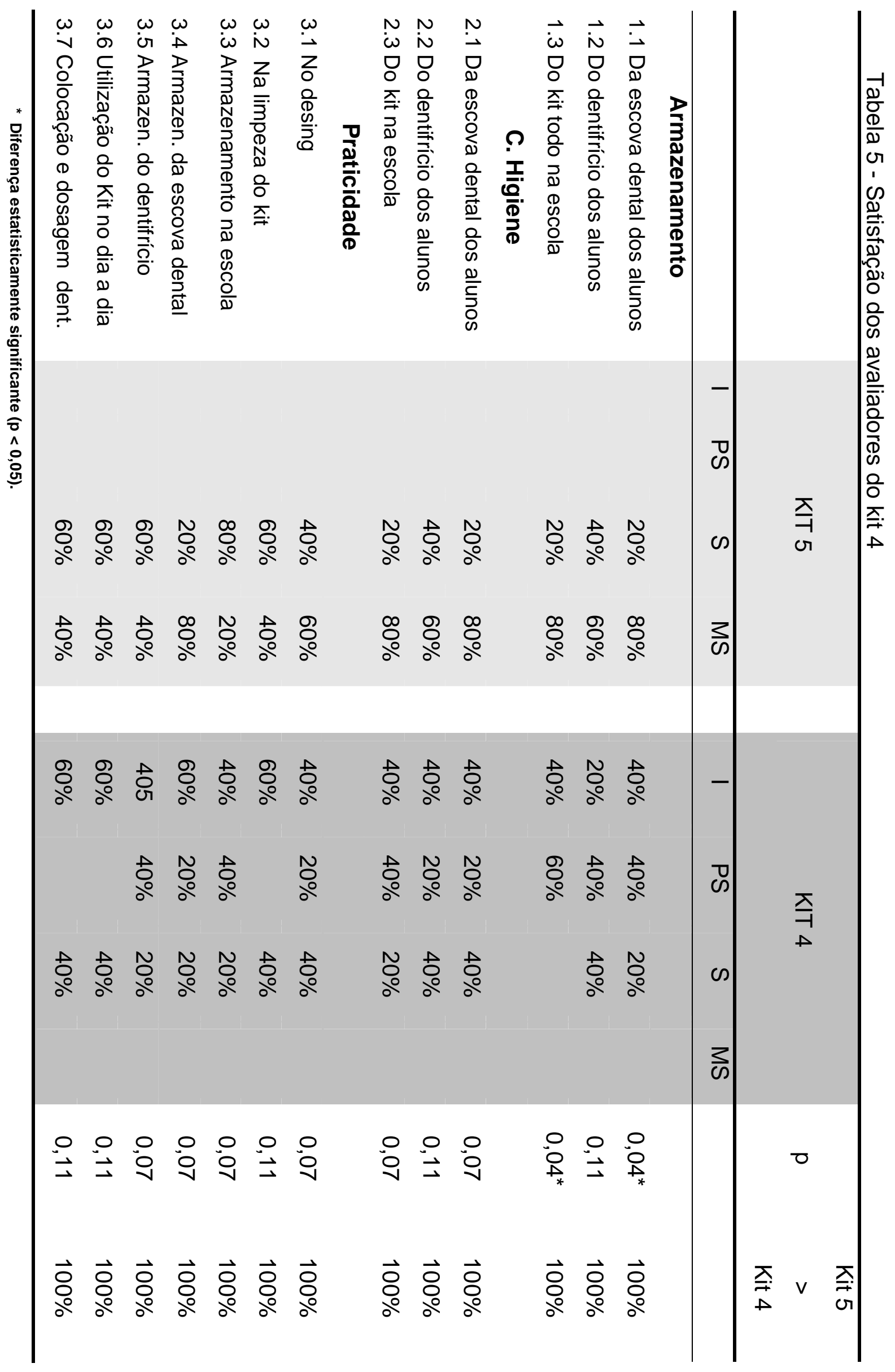


Tabela 6 - Média dos escores obtidos em cada quesito avaliado em relação ao Kit experimental e o Kit Controle $n^{0} 1$.

\begin{tabular}{cccc}
\hline & KIT 5 & KIT 1 & P \\
\hline Armazenamento & 2,27 & 0,47 & $0,04^{*}$ \\
C. higiene & 2,13 & 0,66 & $0,04^{*}$ \\
Praticidade & 2,17 & 0,57 & $0,04^{*}$ \\
\hline
\end{tabular}

Tabela 7 - Média dos escores obtidos em cada quesito avaliado em relação ao Kit experimental e o Kit Controle $n^{0} 2$.

\begin{tabular}{cccc}
\hline & KIT 5 & KIT 2 & P \\
\hline Armazenamento & 2,87 & 1,66 & $0,04^{*}$ \\
C. higiene & 3,00 & 1,13 & $0,04^{*}$ \\
Praticidade & 2,89 & 1,31 & $0,04^{*}$ \\
\hline * Diferenca estatisticamente significante $(p<0,05)$ &
\end{tabular}

* Diferença estatisticamente significante $(p<0,05)$.

Tabela 8 - Média dos escores obtidos em cada quesito avaliado em relação ao Kit experimental e o Kit Controle $\mathrm{n}^{\circ} 3$.

\begin{tabular}{cccc}
\hline & KIT 5 & KIT 3 & P \\
\hline Armazenamento & 2,33 & 1,46 & $0,04^{*}$ \\
C. higiene & 2,00 & 1,27 & 0,07 \\
Praticidade & 2,08 & 1,57 & 0,34 \\
\hline * Diferença estatisticamente significante $(\mathfrak{p}<0,05)$ &
\end{tabular}

* Diferença estatisticamente significante $(p<0,05)$.

Tabela 9 - Média dos escores obtidos em cada quesito avaliado em relação ao Kit experimental e o Kit Controle $n^{\circ} 4$.

\begin{tabular}{cccc}
\hline & KIT 5 & KIT 4 & $\mathrm{P}$ \\
\hline Armazenamento & 2,73 & 0,86 & $0,04^{*}$ \\
C. higiene & 2,73 & 0,93 & $0,04^{*}$ \\
Praticidade & 2,54 & 0,80 & $0,04^{\star}$ \\
\hline
\end{tabular}

* Diferença estatisticamente significante $(p<0,05)$. 
Os gráficos de 14 a 16 ilustram os resultados obtidos através das medianas das respostas sobre cada kit em cada quesito.

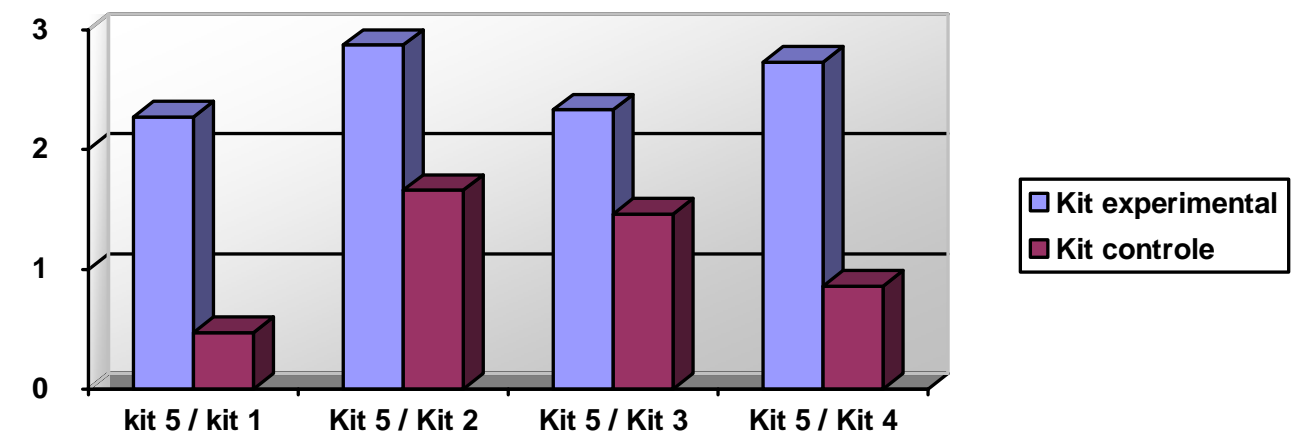

Figura 14 - Comparação entre os kits quanto ao armazenamento.

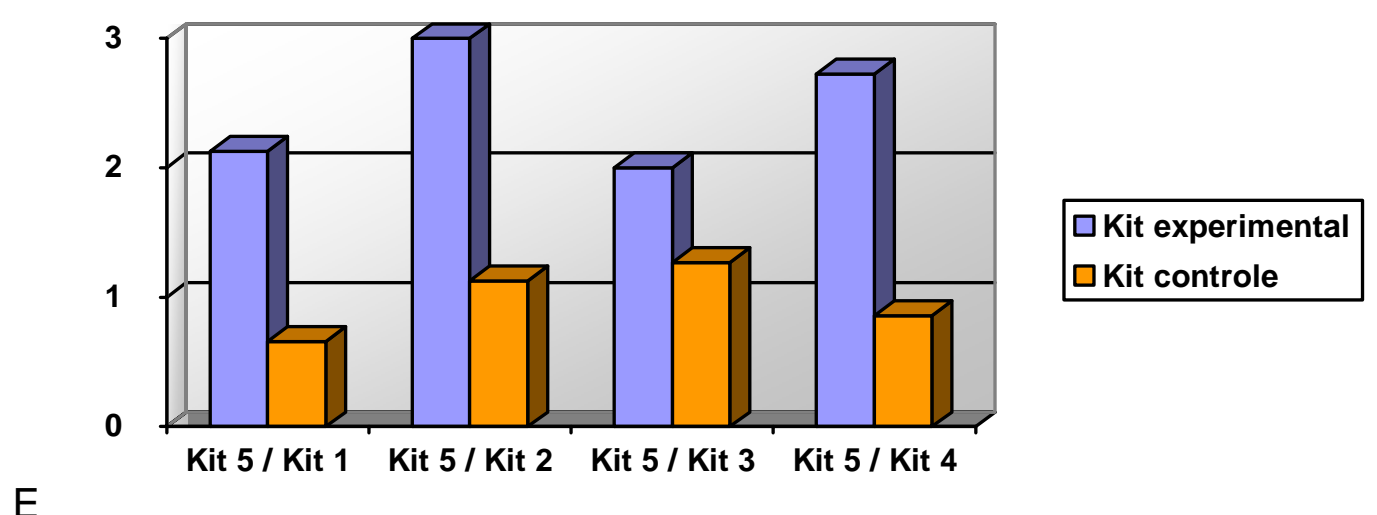

Figura 15 - Comparação entre os kits quanto a higiene.

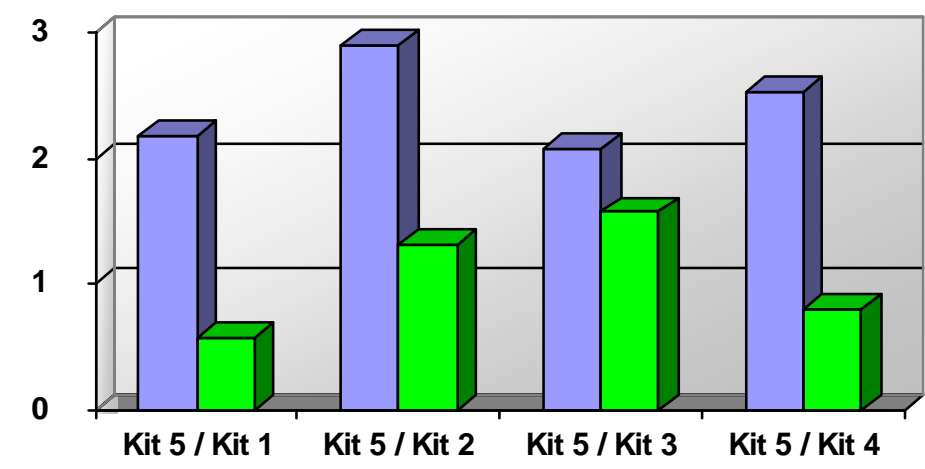

Figura 16 - Comparação entre os kits quanto a praticidade. 
Em relação aos resultados da segunda etapa do trabalho proposto, os escolares de Bauru dispensaram em média 0,41 $\mathrm{g}$ de pasta de dente, e os de Bariri, 0,48g. Já o dentifrício líquido o resultado foi diferente, sendo 0,15 g para Bauru e 0,14 para Bariri.

Durante a aplicação da pasta de dente, foi observado que as crianças de 4 e 5 anos utilizaram a técnica transversal (figura 3 e 17), e as de 8 anos a técnica longitudinal. As crianças de 6 e 7 anos, utilizaram as 2 técnicas. (figura 18)

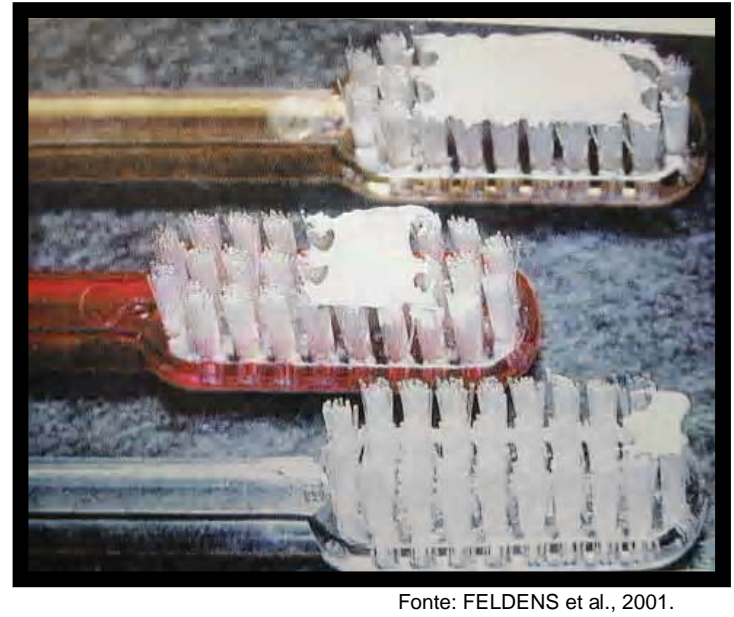

Figura 17 - Quantidade de dentifrício aplicada nas técnicas "longitudinal", "transversal" e "pouquinho", seguindo a ordem de cima para baixo.

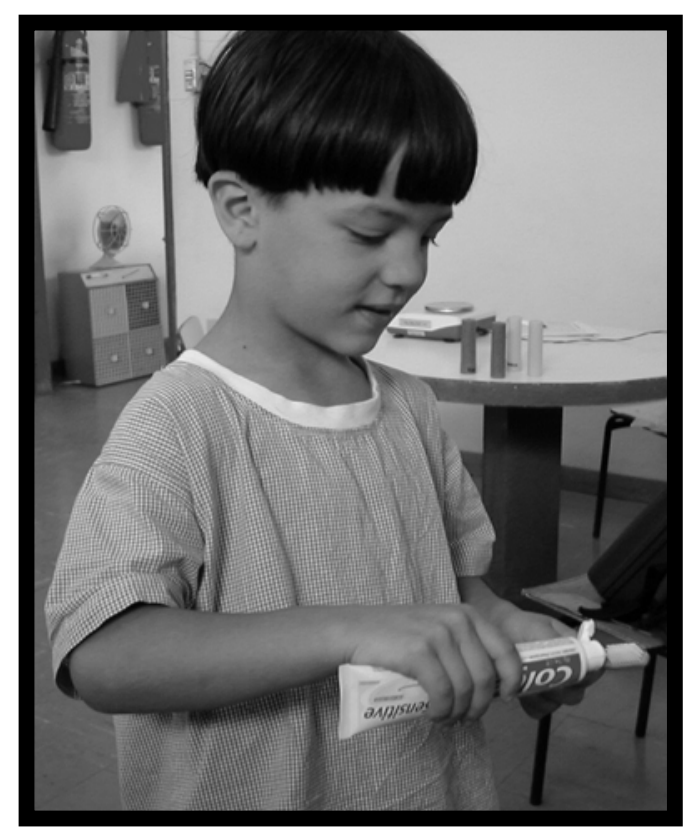

Figura 18 - Criança aplicando o creme dental. 


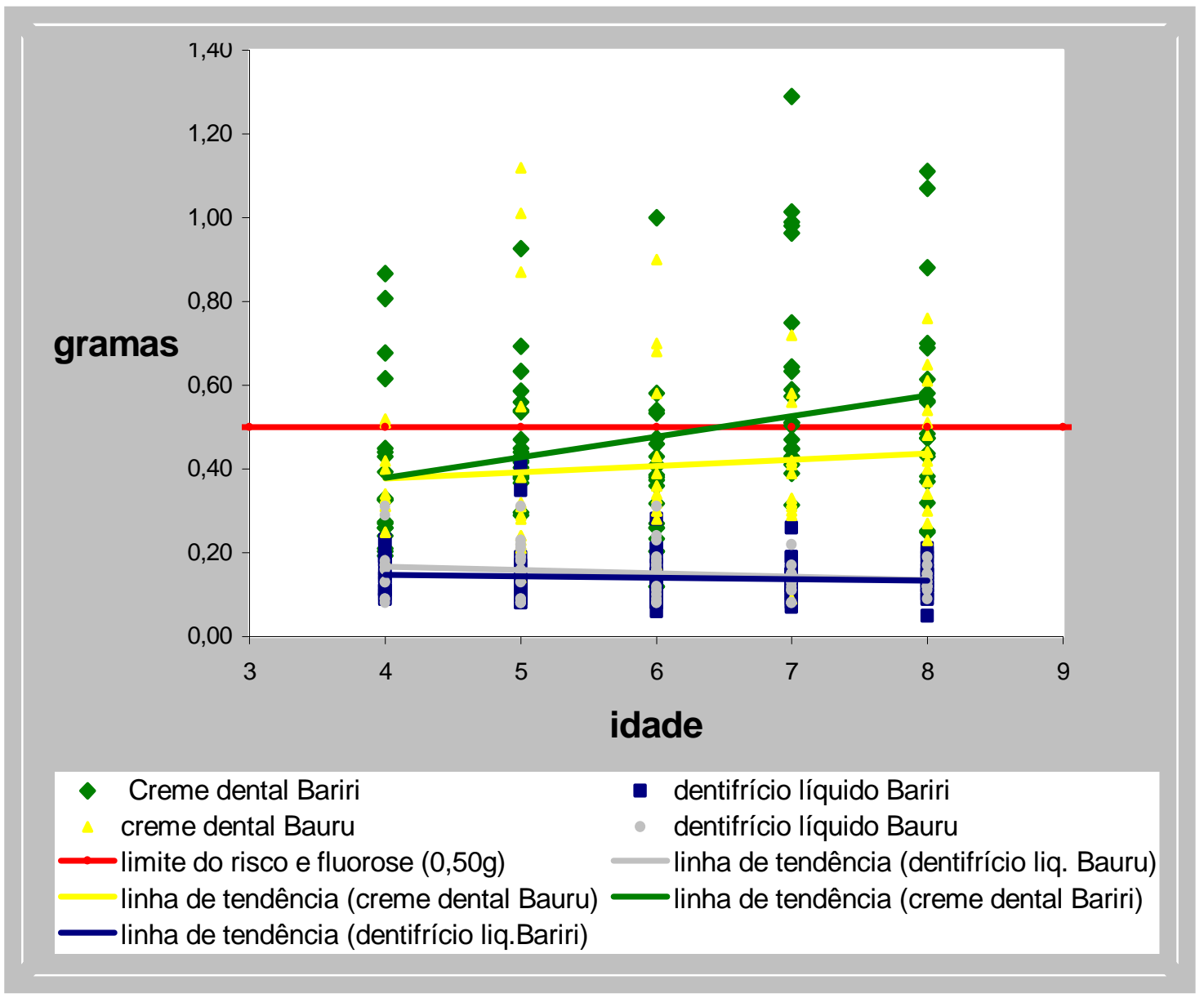

Figura 19 - Gráfico de tendências das quantidades dos dentifrícios dispensados por cada idade.

Verificou-se correlação estatisticamente significante em relação a quantidade de pasta de dente dispensada pelos escolares e a idade $(r=0,20 p$ =0,005). Já em relação ao dentifrício líquido não houve correlação estatisticamente significante.

A análise de covariância (ANCOVA) mostrou interação estatisticamente significante entre as cidades e os dentifrícios. Para o creme dental, o teste indicou diferença estatística entre Bariri e Bauru ( $F=4,57$ / $p=0,034)$. Contudo para o dentifrício líquido não houve diferença estatística ( $F=1,71 / p=0,193)$. Os resultados obtidos na comparação entre creme dental e o dentifrício líquido 
mostraram diferença estatística tanto em Bariri $(F=111,93 / p=0,000)$ quanto em Bauru ( $F=226,93 / p=0,000)$. Um resumo dos resultados se encontra na tabela 10.

Tabela 10 - Média e desvio padrão da quantidade de cada dentifrício dispensada por cidade.

\begin{tabular}{ccc}
\hline & Bariri & Bauru \\
\hline Media (dp) & Media (dp) \\
\hline Creme Dental & $0,48 g(0,24)^{A}$ & $0,41(0,20)^{B}$ \\
Dentifrício Líquido & $0,14 \mathrm{~g}(0,05)^{\mathrm{C}}$ & $0,15(0,06)^{\mathrm{C}}$ \\
& & \\
Letras diferentes mostram diferença estatisticamente significante. Letras \\
iguais mostram que não houve diferença estatisticamente significante.
\end{tabular}

Os valores gastos em cada kit são mostrados na tabela 11.

Tabela 11 - Relação de custos por aluno/ano em reais dos kits estudados para cada sala de aula com 40 alunos.

\begin{tabular}{|c|c|c|c|c|c|}
\hline & Kit 1 & Kit 2 & Kit 3 & Kit 4 & Kit 5 \\
\hline 4 Escovas & 0,80 & 0,80 & 0,80 & 0,80 & 0,80 \\
\hline 4 Dentifrícios & 3,20 & 3,20 & 3,20 & 3,20 & 1,90 * \\
\hline Armazenamento & 1,10 & 0,10 & 0,30 & 0,00 & 1,50 \\
\hline Custo total & 5,10 & 4,10 & 4,30 & 4,00 & 4,20 \\
\hline
\end{tabular}




\section{DISCUSSÃO}

Mesmo com o desenvolvimento de materiais e das técnicas utilizadas na odontologia moderna, a doença cárie dentária e periodontal ainda constituem um grande problema para as nações de todo mundo (MALTZ; CARVALHO ${ }^{33}$, 1997, MALTZ $\left.{ }^{32}, 2000\right)$.

A cárie dentária e a doença periodontal têm como precursores a placa bacteriana, sendo que o controle da placa representa uma medida preventiva fundamental, a qual contribuiu para o declínio das doenças bucais. Sem dúvida alguma a escovação dos dentes com ou sem dentifrício fluoretado foi e continuará sendo o principal meio de controle da placa (BUISHI; AXELSSON ${ }^{10}, 1997$, WALTER; FERELLE ${ }^{67}, 1997$, MOURA et al. ${ }^{35}$, 2000).

A higiene dentária deve começar desde o surgimento do primeiro dente, pois a criança deve incorporar este hábito no seu dia-a-dia (VILHENA $\left.{ }^{61}, 1998\right)$.

Dada a importância desta prática na formação do indivíduo, a escola, por seu significado na vida da criança, tem papel formador destacado e deve assumir explicitamente a responsabilidade por uma educação para a saúde, já que a formação de conceitos, procedimentos e atitudes relativas a ela estão fortemente associadas a valores que o professor e toda a comunidade escolar transmitirão inevitavelmente na vivência cotidiana.

O dia a dia do aluno na escola se faz de vários momentos, os quais estão intimamente relacionados à rotina educacional (VILHENA $\left.{ }^{61}, 1998\right)$.

O momento em que a criança sai de casa uniformizada, o seu traslado de chegada e saída da escola, os materiais adequados para serem utilizados (livros, cadernos, lápis, borracha, caneta, materiais para alimentação, materiais de higiene, etc.), todos se fazem necessários, pois a rotina de hábitos do dia da 
criança na escola não pode estar incompleta, tal qual o ato de lavar as mãos antes das refeições deve preceder a prática da higiene bucal. Devemos entender que a rotina da higiene também é feita na escola, e é composta também pelos cuidados bucais.

Programas odontológicos realizados em escolas são capazes de motivar e orientar os alunos quanto à prática dos hábitos de higiene bucal (NAVARRO et al. $\left.^{38}, 1996\right)$.

Devido o aprendizado em grupo e com o grupo, a motivação da criança através do programa, transcende o ambiente escolar, contagiando a família, sendo que o conhecimento adquirido acompanhará o indivíduo por toda vida (VILHENA $\left.{ }^{61}, 1998\right)$.

Planejamento é peça fundamental para a concretização de um programa (FRAZÃO; NARVAI $\left.{ }^{19}, 1996\right)$.

Atividades de curta duração, sem motivação e material inadequado mostram experiências negativas, e levam ao fracasso diversos programas. (CONRADO et al. $\left.{ }^{13}, 1997\right)$.

Programas odontológicos baseados em ações educativas capazes de motivar, através de atividades e materiais adequados, e também em ações preventivas, prática da escovação dentária e aplicações de flúor, são fadados ao sucesso, já que a devida importância é dada ao binômio educação - prevenção (CONRADO et al. ${ }^{13}, 1997$, GARCIA $^{20}$ et al., 1998, GOMES FILHO et al. ${ }^{22}, 1999$, RAMONA; PETRY ${ }^{45}$, 2002).

Além das ferramentas físicas, como jogos educativos, palestras informativas, livros sobre cuidados com a saúde bucal, kits de higiene bucal, também se faz necessário o caminho de se transmitir os conhecimentos ao 
público alvo. Em se tratando de programas escolares, o alvo são as crianças, as quais necessitam de uma boa forma de transmissão do conhecimento. Personagens Infantis, como o Escovinha e sua turma, demonstraram ser eficazes no trato com os escolares, pois na verdade as crianças se identificam com os personagens, por também serem crianças, facilitando o aprendizado(VILHENA ${ }^{64}$, 2003, VILHENA $\left.{ }^{63}, 2000\right)($ figura 2).

Muitas vezes mesmo com as ferramentas certas para a execução de programas odontológicos que contribuiriam muito para a saúde da população, ainda assim o insucesso acontece.

A falta de interesse político no Brasil por estas ações continua sendo grande. Porém exemplos positivos tal como o município de Blumenau ${ }^{47}$, o qual desde 1991, instituiu a obrigatoriedade da escovação dentária diária nas escolas e o próprio governo federal, através do Brasil Sorridente ${ }^{9}$ em 2004 mostraram que com boa vontade e decisões assertivas muito se pode fazer pela saúde do povo brasileiro.

Outra dimensão importante a ser considerada é aquela referente às formas de implementação das ações. Estudos têm apontado que aspectos relacionados à logística destes processos podem ser tão relevantes na produção dos efeitos quanto as tecnologias preventivas propriamente ditas (CHAVES; VIEIRA - DA SILVA $^{12}$, 2002).

Ou seja, qual a importância de uma lei de implementação de escovação diária, na escola, sem uma forma adequada de armazenamento e distribuição do material de higiene bucal?

Exemplos negativos de imposições governamentais existem, tal qual a introdução do kit de primeiros socorros nos veículos. Esta lei não permaneceu, 
pois sem condições adequadas de treinamento e uso, o motorista não sabia como usar.

Segundo $\mathrm{KWON}^{27}$, 2000, a qualidade física das escovas dentais são fundamentais para proporcionar resultados eficazes, sendo que, elas devem ser sempre limpas, secas e armazenadas de maneira que se conservem satisfatórias por um período razoável de tempo.

Poucos são os estudos e muitas são as iniciativas de se criar um kit de armazenamento do material de higiene bucal, o qual tenha uma logística prática e eficiente.

Mesmo que as iniciativas sejam bem intencionadas, o que têm se verificado são condições higiênicas sanitárias insatisfatórias no armazenamento do material de higiene bucal (SILVEIRA et $\left.\mathrm{al}^{55}, 2000\right)$.

Este trabalho mostrou além de algumas formas de armazenamento e uso do material de higiene bucal, o grau de satisfação dos responsáveis pela prática da escovação dentária dos escolares em relação a estes kits.

Nas tabelas 2, 3, 4, 5, encontra-se os graus de satisfação dos responsáveis em relação aos kits conforme anexo I.

Em algumas das questões não foram encontradas diferenças estatisticamente significantes $(p>0,05)$.

Mesmo assim, devido ao formato do estudo, através do anexo II, o qual está descrito em cada tabela na coluna Kit 5 ( experimental ) > Kit controle (1 à 4), pôde -se verificar a porcentagem de preferência pelo kit 5.

Analisando a tabela 2, verificou-se que apenas não existiu diferença estatisticamente significante nas questões 3.2, 3.4, 3.6. Contudo o grau de preferência em todas as questões foi de $100 \%$ para o Kit 5 . Além disso o grau de 
satisfação na questão 3.2 foi de $60 \%$ satisfeito em relação ao Kit 5 e 60\% insatisfeito para o Kit 1. Para a questão 3.4, 80\% estavam satisfeitos com o Kit 5 e $60 \%$ estavam insatisfeitos com o Kit 1. Já em relação a questão 3.6, 80\% dos pesquisados ficaram satisfeitos com o Kit 5 e 60\%insatisfeitos com o Kit 1.

Quando observado os escores obtidos em relação a cada questão (tabela 6), o Kit 5 foi $100 \%$ estatisticamente significante em relação ao kit 1, demonstrando a preferência dos pesquisados pelo kit 5. Estes dados são melhores visualizados através das figuras 14, 15, 16, onde verificou-se que o Kit 5 obteve escores acima de 2 na forma de armazenamento, higiene do material e praticidade, confirmando o grau de satisfação pelo Kit 5. Já o Kit 1 obteve em média escores entre 0 e 1 nos quesitos analisados, demonstrando pouca ou nenhuma satisfação em relação ao kit 1.

Um dos motivos que também contribui para a insatisfação em relação ao kit 1 foi o seu design. Provavelmente pelas grandes medidas, o seu armazenamento na escola ficou comprometido, pois para guardar os kits de cada aluno, ocupa - se muito espaço dentro da sala de aula, diferentemente do kit 5 (figuras 20 e 21).

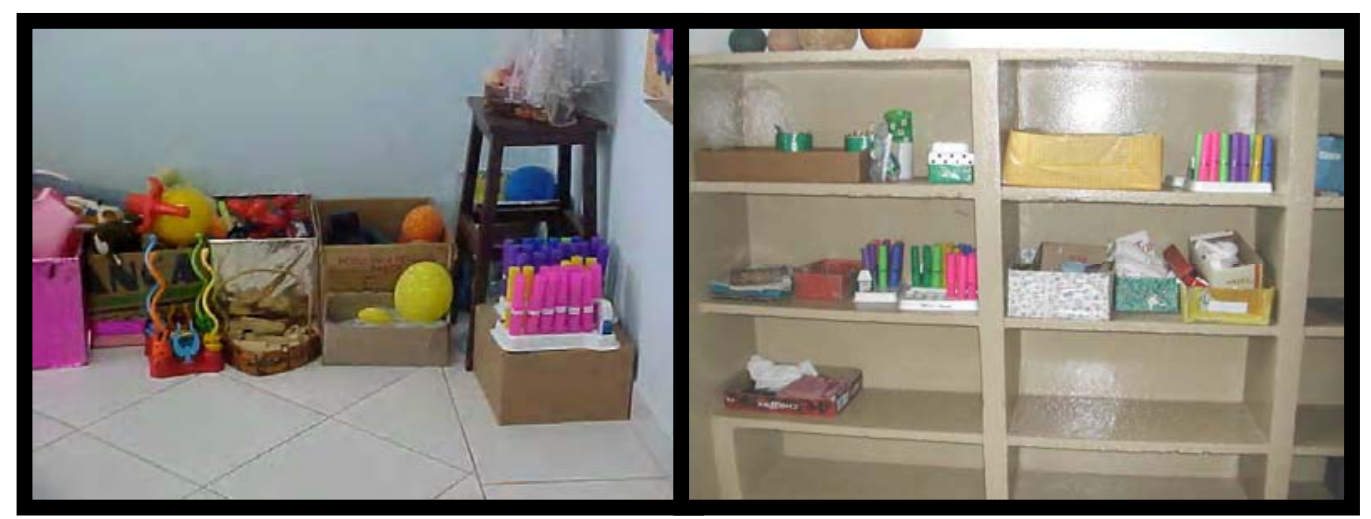

Figura 20 e 21 - Armazenamento em sala de aula do kit 5. 
O Kit 5 quando comparado ao kit 2 (tabela 3), verificou-se que não houve diferença estatisticamente significante nas questões 1.1, 1.3, 3.3, 3.6. Porém a preferência pelo kit 5 nestes quesitos tiveram uma média de 85\%.

Além disso, $100 \%$ dos pesquisados ficaram muito satisfeitos com o Kit 5 em relação ao armazenamento das escovas dos alunos (questão 1.1). Para o kit 2, $60 \%$ ficaram pouco satisfeitos. No quesito armazenamento do kit na escola (questão 1.3), 80\% demonstraram muito satisfeitos com o kit 5 e $60 \%$ pouco satisfeitos com o kit 2. Quando questionados em relação a praticidade do armazenamento do kit na escola, 80\% demonstraram muita satisfação em relação ao kit 5, e com o kit 2, 40\% satisfeitos. Para a questão que avaliava a utilização do kit no dia a dia (3.6) o resultado de $80 \%$ de muita satisfação foi encontrado para o kit 5 contra $80 \%$ de apenas satisfeitos. Estes resultados encontrados nas ultimas 2 questões referentes a praticidade, se referem a realmente o quão prático é o kit 2. No entanto, este tipo de armazenamento é bastante utilizado para jogos de ferramentas, estojos de lápis, etc, e foi adaptado para o armazenamento da escova dental. Quando se questiona as condições higiênicas e sanitárias deste tipo de armazenamento, pôde - se verificar que o mesmo é totalmente reprovado, pois no ato de enrolar o kit existe o contato entre as escovas e as mesmas nunca são guardadas no mesmo lugar.

Analisando a tabela 6 , verifica-se que houve diferença estatisticamente significante entre os kit 5 e 2 em todos os grupos de questões.

Esta preferência pelo kit 5 em relação a kit 2 foi comprovada também através dos resultados demonstrados nas figuras 14, 15, 16. O kit 5 atingiu 100\% de satisfação, isto é, os resultados indicaram muita satisfação na utilização do kit 5 em todos os quesitos. Já o kit 2 obteve médias de 1,33, 1,33, 1,00 
respectivamente para armazenamento, condições de higiene e praticidade, sendo comprovada a pouca satisfação em relação ao kit 2.

Outro ponto a ser ressaltado é que os avaliadores do kit 2, são professores da rede municipal de ensino do município de Bauru. Sendo assim os resultados apresentados confirmaram os achados de VILHENA; SALES PERES; BASTOS ${ }^{65}$, 2004, o qual o Kit experimental é uma ferramenta que contribui para a resolução de ações em saúde bucal coletiva dentro do Sistema Único de Saúde (SUS).

De acordo com a tabela 4 verifica-se que os dados obtidos em relação ao kit 3 foram os que menos se diferenciaram do kit 5 analisando questão por questão. Um dos principais motivos deste resultado foi que o desenvolvimento do kit 3 e a sua análise foi realizada por cirurgiões dentistas, os quais são os responsáveis pela higiene bucal dos escolares estudados.

$67 \%$ dos participantes acharam o kit 5 superior em relação ao armazenamento, 60\% superior em relação as condições de higiene, e 63\% superior em relação a praticidade, sendo que nas questões referentes as condições de higiene do dentifrício (2.2), no armazenamento do dentifrício do aluno ( 3.5) e na colocação da dosagem do dentifrício para cada aluno (3.7) o kit 5 obteve $100 \%$ de satisfação.

$\mathrm{Na}$ tabela 8, os resultados mostraram diferença estatisticamente significante em relação ao armazenamento $(p=0,04)$.

O dado anterior foi ilustrado na figura 14. Através deste gráfico, verificou-se que o kit 5 se encontra na faixa entre satisfeito e muito satisfeito. O mesmo não ocorre com o kit 3, o qual está entre satisfeito e pouco satisfeito. 
Para os quesitos de condições de higiene e praticidade, figuras 15 e 16, os resultados foram os mesmos descritos em relação ao armazenamento, ou seja, kit 5 entre muito satisfeito e satisfeito e kit 3 entre satisfeito e pouco satisfeito.

Ainda em relação às tabelas 4,8 e as figuras 14,15,16, verificou-se que devido a necessidade de se trocar os sacos plásticos de armazenamento, todas as vezes depois da higiene bucal dos alunos, possivelmente contribuiu para a pouca satisfação em relação ao kit 3 tanto no armazenamento, quanto na praticidade no dia a dia. Além disso, o design do kit 5 foi superior, o qual proporcionou o acondicionamento de todo o material. O dentifrício na forma líquida possivelmente também contribui muito para a superioridade do kit 5 em relação ao kit 3.

Analisando a tabela 5, observou - se que houve diferença estatisticamente significante nas questões referentes ao armazenamento, isto é, da escova (1.1) e do kit na escola (1.3). A porcentagem de preferência pelo kit 5 em relação ao kit 4 foi de $100 \%$ para todas as questões, comprovando a superioridade do kit 5 . Vale também ressaltar que as respostas em relação ao kit 5 ficaram entre satisfeito e muito satisfeito. Já em relação ao kit 4 o resultado encontrado na maior parte das respostas encontraram -se na coluna de insatisfeito, seguido por pouco satisfeito, e uma pequena parcela de satisfeito.

Na tabela 9 a comparação entre os kits se mostrou diferente. Em todos os quesitos, ou seja, armazenamento, condições de higiene e praticidade, houve diferença estatisticamente significante, com superioridade a favor do kit 5.

Esta superioridade foi ilustrada nas figuras 14, 15, 16.

Na tabela 9, ilustrado na figura 14 , observou-se o escore referente ao armazenamento de 2,73 para o kit 5. Isto representa um grau de satisfação e 
muita satisfação. Para o kit 4 o escore foi 0,86 (pouco satisfeito e insatisfeito). Este resultado representa um índice de pouca satisfação.

Ainda de acordo com a tabela 9, ilustrada na figura 15, a diferença foi semelhante a anterior. O escore atingido foi de 2,73 para o kit 5, e 0,93 para o kit 4 em relação as condições de higiene do material de escovação dentária coletiva. No quesito praticidade, ilustrado na figura 16 , os escores foram 2,54 para o kit 5 e 0,80 para o kit 4. Este resultado demonstrou que os responsáveis pela higiene bucal ficaram satisfeitos e muito satisfeitos com o kit 5 e insatisfeitos e pouco satisfeitos com o kit 4.

A segunda etapa do trabalho além de confirmar os gastos de cada dentifrício, contribuiu também para sugerir soluções em relação ao consumo excessivo de dentifrício.

Nos últimos anos a prevalência da fluorose dentária tem aumentado em comunidades com e sem água fluoretada (VILLENA ${ }^{66}, 2000$, NARVAI $\left.^{37}, 2000\right)$.

O flúor ainda é considerado o principal agente terapêutico em relação cárie dentária contribuindo para o declínio desta doença (BASTOS; LOPES ${ }^{5}, 2001$, CURY $^{16}, 2002$, OLIVEIRA et $\mathrm{al}^{39}$. 2001, SILVA $^{51}, 2000$, NARVAI $\left.^{37}, 2000\right)$.

Deve se ressaltar que o $F^{-}$é o responsável pela ocorrência da fluorose dentária. Este problema compromete a estética dos dentes, podendo até comprometer a saúde bucal de crianças menores de 7 anos que fazem à ingestão inadequada do flúor, ingerindo doses maiores que 0,05 a 0,07 mgF/Kg/dia. $\left(\right.$ CURY $\left.^{15}, 2001\right)$ 
Segundo CURY ${ }^{15}, 2001$, a estratégia para um melhor risco / benefício deveria ser uma que minimizasse a quantidade de flúor ingerida e maximizasse a concentração de flúor disponível no meio bucal.

A principal via de ingestão do flúor se dá através do dentifrício fluoretado, sendo ele o principal responsável pela fluorose. (NARVAI ${ }^{37}, 2000$, FELDENS et al. $^{18}, 2001$, LIMA; CURY $\left.{ }^{28}, 2001\right)$.

Segundo $\mathrm{MOSS}^{34}, 1996$, (figura 22) uma pequena quantidade de pasta é tudo para executar uma boa limpeza dos dentes. Porém o que até pouco tempo atrás era considerado uma quantidade ideal de uso do dentifrício, hoje já não é mais.

Fonte: MOSS, 1996

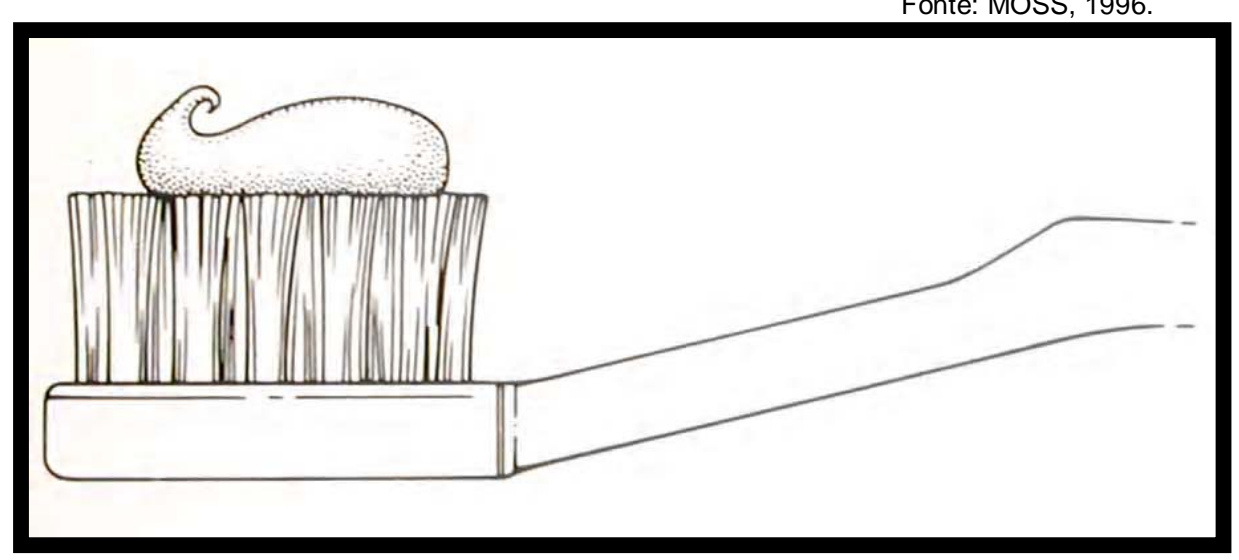

Figura 22 - llustração de "pequena" quantidade de pasta de dente que deveria ser usada.

O marketing apelativo através de uma infinidade de anúncios e propagandas confunde a população a respeito da quantidade correta de dentifrício a ser usada. O dentifrício em algumas veiculações de propaganda televisiva foi usado até como gel de cabelo para ser mais vendido.

Considerando-se que as crianças menores de 6 anos de idade ingerem involuntariamente dentifrícios quando escovam os dentes, medidas devem ser tomadas para sua redução. (CURY $\left.{ }^{15}, 2001\right)$. 
Na figura 17, uma correlação estatisticamente significante foi verificada em relação à quantidade de creme dental dispensado pela amostra e a idade. Estes dados confirmam a observação feita durante a pesquisa, onde foi verificado que uma pequena quantidade de pasta de dente foi dispensada pelos escolares de baixa idade em relação às outras crianças. Crianças de 4 e 5 anos foram beneficiadas por não terem habilidade manual suficiente para usarem a "técnica longitudinal" de aplicação do creme dental. Por isso, utilizam naturalmente a "técnica transversal" (figura 18) .

Com o dentifrício líquido isto não aconteceu. Não houve correlação estatisticamente significante devido à padronização da quantidade utilizada através da "técnica da gota" (figura 6).

Crianças de Bauru dispensaram em média 14,6\% menos pasta de dente do que as crianças de Bariri. Este fato provavelmente se deve as ações que os escolares de Bauru recebem, as quais fazem parte de orientações constantes dos acadêmicos da Faculdade de Odontologia de Bauru, comprovando também a eficácia de um programa mais intensivo de educação e prevenção.

Também foi observado que a quantidade de dentifrício líquido dispensada pela amostra total (Bauru e Bariri) foi em média três vezes menor do que a quantidade dispensada de creme dental. Este resultado demonstrou a facilidade na dosagem do dentifrício líquido, visto que independe da criança ter recebido ou não orientação.

Desde que o dentifrício passou a ter flúor em sua composição, o mesmo assumiu uma função terapêutica (NARVAl ${ }^{37}, 2000$, FELDENS et al. $^{18}$, 2001), e deve ser dosado como todos os medicamentos. 
Muitas são as formas de se tentar padronizar a quantidade de dentifrício dispensado pelas crianças (VILLENA ${ }^{66}, 2000$, BENTLEY $^{7}$ et al., 1997, AYSEGUL $^{4}$ et al., 2004, VILHENA; SALES PERES; BASTOS ${ }^{65}$ ).

No Reino Unido e na Comunidade Européia além da fórmula tradicional do creme dental, a fórmula líquida é amplamente utilizada e disponibilizada no mercado. Existe uma linha completa da Colgate de dentifrícios líquidos, desde o tipo kids, até o tradicional, ação total e clareador.

O bico dosador do dentifrício líquido administra uma quantidade controlada de dentifrício através da "gota". (figura 6)

Cada gota tem média 0,15g e não um "pouquinho" ou um "grão de ervilha" como literatura tem demonstrado (figura 19) $\left(\right.$ VILLENA $^{66}, 2000$ BENTLEY $^{7}$ et al., 1997, AYSEGUL ${ }^{4}$ et al., 2004, VILHENA; SALES PERES; BASTOS ${ }^{65}$ ). Estas quantidades("pouquinho" e " grão de ervilha") são muito subjetivas e variam de pessoa para pessoa.

Ainda de acordo com a literatura (VILLENA ${ }^{66}, 2000$, LIMA; CURY $\left.^{28}, 2001\right)$ crianças não devem usar mais do que $0,50 \mathrm{~g}$ de dentifrício, devido ao risco de fluorose dentária. Uma amostra de 24,6\% dos escolares de Bauru e em 31,4\% de Bariri aplicou uma quantidade maior de pasta de dente do que deveriam, excedendo a marca limite de acordo com a figura 17. o mesmo não aconteceu com o dentifrício líquido, pois nenhum escolar aplicou mais do que 0,50g.

Em se tratando da saúde coletiva dos escolares, medidas quanto à biosegurança devem ser tomadas, para evitar a propagação das enfermidades.

Pode - se afirmar que escovas dentais são reservatórios de bactérias provenientes da microbiota bucal e outras fontes de contaminação (SVANBERG ${ }^{56}, 1978$, PINTO et al. ${ }^{41}$ 1997, TAJI; ROGERS $\left.{ }^{57}, 1998\right)$. 
Diversas foram às pesquisas que buscaram um meio apropriado para evitar a proliferação de bactérias no material de higiene bucal. (LONG et al ${ }^{30}, 2000$, SILVEIRA ET AL. ${ }^{54}, 2002$, QUIRYNEM et al. $\left.{ }^{44}, 2003\right)$

Não se deve propor a esterilização das escovas, visto que não existe razão para isto. O que deve ser pesquisado são soluções práticas para o uso do material no dia a dia dos programas escolares.

Como medida de biosegurança em saúde pública, nos ambientes coletivos (bares, restaurantes, shoppings, etc.) foi adotada o uso do sabonete líquido para evitar o acúmulo de bactérias nos sabonetes em barra, os quais até pouco tempo atrás foi muito utilizado.

O dentifrício na forma líquida, através do bico dosador permite a aplicação na escova sem contato com a cerda, minimizando o risco de transmissão das bactérias entre os escolares (figura 6).

Na tabela 11, encontram - se os custos de todos os kits. Por ano o consumo médio de um escolar é de 4 escovas dentais e 4 tubos de creme dental de 90g. A única exceção, é que para o kit 5 o dentifrício utilizado foi na forma líquida. Esta diferença no kit 5 proporcionou um menor preço total na comparação entre todos os outros, pois além de um consumo menor, o bico dosador preveniu o desperdício.

$\mathrm{Na}$ comparação direta entre os kits, o kit 5 demonstrou ter um custo bastante acessível, encontrando-se entre os mais baratos.

Por um pensamento lógico e simples, se o dentifrício líquido fosse adotado em todos os kits, o kit 5 seria o mais caro.

Porém a preferência pelo kit 5 não está no custo, mas em todo o seu conjunto. 
O que se questiona neste aspecto não é apenas o preço do produto, mas sim um conjunto de medidas que deve fazer parte de um material adequado para a prática da escovação dentária coletiva.

Os kits de 1 à 4 possuíram problemas nos aspectos de praticidade, armazenamento e condições de higiene.

Além da preocupação por parte das escolas com a forma de armazenar e distribuir escovas e dentifrícios cabe também aos governantes (esferas municipal, estadual ou federal) entenderem que além de distribuírem o material para a prática da higiene, deve se pensar em como será esta prática.

Como foram armazenados e utilizados os 2.000 .000 de kits de higiene bucal (escova e pasta de dente) distribuídos a 500.000 escolares pelo Programa Brasil Sorridente ${ }^{9} ?$

O material é somente um dos responsáveis pela manutenção da saúde. Com tantas tecnologias, a forma de armazenar, como distribuir, e como proceder durante a prática da escovação não deve ser deixada para segundo plano, e muito menos sem planejamento.

Não existe argumento para contestar a compra também de uma forma adequada de se armazenar o material de higiene bucal coletiva, visto que o custo é irrisório.

Conforme CONRADO et al. ${ }^{13}, 1997$, o sucesso de um programa depende da habilidade e do interesse do educador. Uma das preocupações deve estar pautada na motivação de educadores, os quais poderão atuar como agentes multiplicadores de saúde, e necessitarão de material e condições adequadas para o desenvolvimento desta função. 
Os profissionais de saúde devem ter em mente que a prática da saúde bucal é algo relevante, que deve ser desenvolvida em um ambiente coletivo, escolar, e tratada individualmente, com a devida atenção.

A escova dentária, instrumento indispensável para a manutenção da saúde, deve ser armazenada em local adequado, e não como ferramenta tipo chave de fenda (kit 2), ou armazenada em porta lápis ou garrafa de refrigerante cortada ao meio, exposta a todo tipo de contaminação(kit 4). Muito menos dentro de saquinhos ou embalagens fechados sem circulação de ar (kits 1 e 3), transformando as escovas em verdadeiros depósitos de microrganismos.

Um kit ideal para a prática de higiene bucal coletiva, deve ter um suporte coletivo para armazenamento de todo o material, que ocupe um menor espaço (figura 20 e 21). As escovas devem ser secas e mantidas em recipientes individuais fechados e com ventilação, tal qual preconizado VILHENA; SALES PERES; BASTOS ${ }^{65}, 2004$, para evitar a contaminação. (SVANBERG ${ }^{56}, 1978$, LONG et al. ${ }^{30}, 2000$, SILVEIRA et al. ${ }^{54}, 2002$, QUIRYNEM et al. ${ }^{44}, 2003$ )

O dentifrício deve ser aplicado de forma que o bico do tubo não tenha contato com as cerdas das escovas dos alunos, e também deve ser dosado para evitar o risco de fluorose dentária. Atualmente o dentifrício na forma líquida se enquadra perfeitamente nestas características. 


\section{CONCLUSÕES}

Através deste estudo, pode - se concluir que:

- O Kit 5 foi superior aos demais kits satisfazendo aos avaliadores nos aspectos de armazenamento, condições de higiene e praticidade;

- Os escolares dispensaram 3 vezes mais creme dental quando comparado ao uso do dentifrício líquido;

- O dentifrício líquido pode ser facilmente utilizado através da "técnica da gota", dispensando uma pequena quantidade padronizada de dentifrício;

- O kit 5 demonstrou ser a melhor forma de armazenamento e distribuição do material de higiene bucal do escolar 
FACULDADE DE ODONTOLOGIA DE BAURU

DEPARTAMENTO DE ODONTOPEDIATRIA, ORTODONTIA E

SAÚDE COLETIVA

Dr. Octávio Pinheiro Brisolla, 9-75 - Bauru-SP - CEP:17043-101

.73 - PABX: (014) 235-8000 - email - escovinha@escovinha.com.br

\section{ANEXO I}

\begin{tabular}{|l|l|l|}
\hline ESCOLA: & \multicolumn{2}{l|}{ CIDADE: } \\
\hline SÉRIE: & PERÍODO: & TEL. CONTATO: \\
\hline KIT: & AVALIADOR: & \\
\hline
\end{tabular}

\section{Avalie os itens dos quadros abaixo conforme o seguinte código:}

MS - MUITO SATISFEITO S - SATISFEITO PS - POUCO SATISFEITO I-INSATISFEITO

1) Armazenamento

\begin{tabular}{|l|l|l|l|l|}
\cline { 3 - 5 } \multicolumn{1}{c|}{} & MS & S & PS & I \\
\hline 1.2 - Do dentifrício dos alunos & & & & \\
\hline 1.3 - Do kit todo na escola & & & & \\
\hline
\end{tabular}

2) Condições de Higiene (acúmulo de água e resíduos )

2.1 - Da escova dental dos alunos

2.2 - Do dentifrício dos alunos

2.3 - Do kit na escola

\begin{tabular}{|l|l|l|l|}
\hline MS & S & PS & I \\
\hline & & & \\
\hline & & & \\
\hline
\end{tabular}

3) Praticidade

\begin{tabular}{|c|c|c|c|c|}
\hline & & \multirow[b]{2}{*}{$\mathbf{S}$} & \multirow[b]{2}{*}{ PS } & \multirow[b]{2}{*}{ I } \\
\hline & & & & \\
\hline 3.1 - No desing & & & & \\
\hline 3.2 - Na limpeza do kit & & & & \\
\hline 3.3 - No armazenamento na escola & & & & \\
\hline 3.4 - No armazenamento da escova dental do aluno & & & & \\
\hline 3.5 - No armazenamento do dentifrício do aluno & & & & \\
\hline 3.6 - Na utilização do Kit no dia a dia & & & & \\
\hline 3.7 - Na colocação e dosagem do dentifrício para cada aluno & & & & \\
\hline
\end{tabular}


FACULDADE DE ODONTOLOGIA DE BAURU

DEPARTAMENTO DE ODONTOPEDIATRIA, ORTODONTIA E

SAÚDE COLETIVA

Dr. Octávio Pinheiro Brisolla, 9-75 - Bauru-SP - CEP:17043-101

.73 - PABX: (014) 235-8000 - email - escovinha@escovinha.com.br

\section{ANEXO II}

\begin{tabular}{|l|l|l|}
\hline \multicolumn{2}{|l|}{ ESCOLA: } & CIDADE: \\
\hline SÉRIE: & PERÍODO: & TEL. CONTATO: \\
\hline KIT: & AVALIADOR: \\
\hline
\end{tabular}

\section{Assinale o Kit com o melhor resultado encontrado para cada ítem:}

\section{1) Armazenamento}

\begin{tabular}{|l|c|c|}
\cline { 2 - 3 } \multicolumn{1}{l|}{} & Kit: & Kit $\mathbf{5}$ \\
\hline Da escova dental dos alunos & & \\
\hline Do dentifrício dos alunos & & \\
\hline Do kit todo na escola & & \\
\hline
\end{tabular}

2) Condições de Higiene (acúmulo de água e resíduos )

\begin{tabular}{|l|l|l|}
\cline { 2 - 3 } \multicolumn{1}{l|}{} & Kit: & Kit $\mathbf{5}$ \\
\hline Da escova dental dos alunos & & \\
\hline Do dentifrício dos alunos & & \\
\hline Do kit na escola & & \\
\hline
\end{tabular}

\section{3) Praticidade}

\begin{tabular}{|l|l|l|}
\cline { 2 - 3 } \multicolumn{1}{l|}{} & Kit: & Kit $\mathbf{5}$ \\
\hline Na desing & & \\
\hline No armazenamento na escola & & \\
\hline No armazenamento da escova dental do aluno & & \\
\hline No armazenamento do dentifrício do aluno & & \\
\hline Na utilização do Kit no dia a dia & & \\
\hline Na colocação e dosagem do dentifrício para cada aluno & & \\
\hline
\end{tabular}


ANEXO III

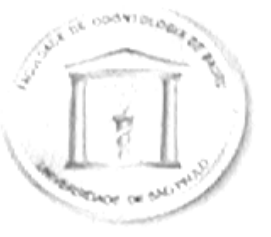

\section{Universidade de São Paulo Faculdade de Odontologia de Bauru \\ AI. Dr. Octávio Pinhciro Brisolla, 9-75 - Bauru-SP - CEP 17012-901 - C.P. 73 PABX (0XX14)3235-8000 - FAX (0XX14)3223-4679 \\ Comitê de Ética em Pesquisa (3235-8356)}

Processo $n^{-92 / 200 \mathrm{~J}}$

Bauru, 21 de setembro de 2004.

Senhora Professora,

Informamos que após o envio da documentação pendente referente ao projeto de pesquisa encaminhado a este Comitê de Ética em Pesquisa "Análise comparativa entre formas de armazenamento e distribuição de escovas e dentifrícios dentais em programa educativo preventivo odontológico para escolares" de autoria de Fabiano Vieira Vilhena, sob sua orientação foi novamente avaliado e considerado APROVADO por este Comitê nesta data.

Lembramos que após o envio do trabalho concluido, este Comitê enviará parecer final, que será utilizado para publicação do trabalho.

Atenciosamente,

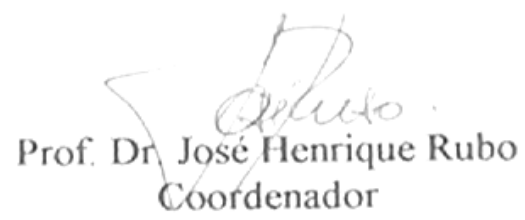

$1 \mathrm{~m} \mathrm{~m}^{\mathrm{a}} \mathrm{Sr} \mathrm{r}^{n}$ Prof" Dr" Magali de Lourdes Caldana

DD. Docente do Departamento de Fonoaudiologia 


\section{ANEXO IV}

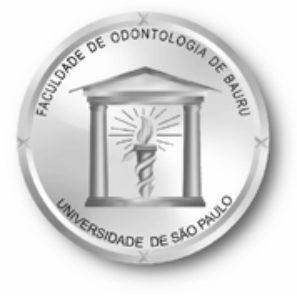

Universidade de São Paulo

Faculdade de Odontologia de Bauru

Al. Dr Octávio Pinheiro Brisolla, 9-75 Bauru SP CEP 17012-901 CP- 73

PABX (0XX14)235-8000 - FAX (0XX14)223-4679

\section{CARTA DE INFORMAÇÃO}

Prezado(a) Sr.(a)

Pedimos o favor de dedicar alguns minutos do seu tempo para ler este comunicado. Estamos fazendo uma pesquisa sobre as condiçòes em que são guardados e distribuidos os materiais de higiene bucal( escovas dentais, dentifrícios, e porta escovas) utilizados pelos alunos. Nessa investigação cientifica, serão avaliadas a forma de armazenamento, as condições de higiene e a praticidade dos materiais citados. A forma de se realizar esta investigação, é apenas a resposta de um questionário pelo responsável pela higiene bucal dos alunos, o qual não representa nenhum desconforto. Além disso, a sala de aula que participar desta investigação, receberá um novo Kit de higiene bucal coletivo. Os resultados da pesquisa ajudarão muito a prevenir doenças bucais e a melhorar a saude de todos.

Por isso a sua colaboração, autorizando a realização da pesquisa é muito importante, sendo que a qualquer momento poderá deixar de participar da pesquisa.

Esperando poder contar com a sua ajuda, boa vontade a disponibilidade, desde ja agradecemos antecipadamente a colaboração, e colocamo-nos a disposição para qualquer esclarecimento.

Caso o Sr(a) queira apresentar reclamações em relação a sua participação na pesquisa, poderá entrar em contato com o Comitê de Ética em Pesquisa em Seres Humanos, da FOB-USP, pelo endereço da Al. Dr. Octávio Pinheiro Brisolla, 9-75 (sala no prédio da Biblioteca, FOB/USP) ou pelo telefone (14)3235-8356.

\section{TERMO DE CONSENTIMENTO LIVRE E ESCLARECIDO}

(a)

Pelo presente instrumento que atende as exigências legais,o Sr. portador da cedula de identidade

após leitura minuciosa da CARTA DE INFORMAÇÃO, devidamente explicada pelo profissional em seus mínimos detalhes, ciente dos procedimentos realizados, não restando quaisquer dúvidas a respeito do lido e explicado, firma seu CONSENTIMENTO LIVRE E ESCLARECIDO concordando em participar da pesquisa proposta.

Fica claro que o participante, pode a qualquer momento retirar seu CONSENTIMENTO LIVRE E ESCLARECIDO e deixar de participar desta pesquisa e ciente de que todas as informações prestadas tomaram-se confidenciais e guardadas por força de sigilo profissional (Art. $9^{\circ}$ do Codigo de Ética Odontológica).

Por estarem de acordo assinam o presente termo.

$$
\text { de de } 200
$$


REFERÊNCIAS BIBLIOGRÁFICAS*

1. AlbuquerQue, S. S. L.; LIMA, M. G. G. C.; SAMPAIO, F. C. Avaliação da utilização de dentifrícios fluoretados em pré-escolares na cidade de João Pessoa - PB - Brasil. Odontologia Clín - Científ, v. 2, n.3, p. 211- 6, set./dez. 2003.

2. ALLE, C. D.; ASHLEY, F. D.; NAYLOR, M.N. Caries experience im 11years - old schoolchildren between 1962 and 1981. Brit Dent J, v.154, n. 6, p 167-70, 1983.

3. AMMARI, B.; BLOCH-ZUPAN, A.; ASHLEY, P. F. Systematic review of studies comparing the anti-caries efficacy of children's toothpaste containing 600 ppm of fluoride or less with high fluoride toothpastes of 1,000 ppm or above. Caries Res, v. 37,n. 2, p. 85-92, 2003.

4. AYSEGUL, O.; DILEK, T.; ELGIN, E. The effects of different application techniques and orifices on the amount of dentifrice. J Clin Ped Dent, v. 28, n.4, p.343 - 6, 2004

5. BASTOS, J. R. M.; LOPES, E. S. Manual de odontologia preventiva, Bauru, s.ed.,2001. p.57.

6. BASTOS, J. R. et al. Considerações a respeito de saúde bucal e classes sociais. Rev Paulista de Odontologia, v. 18, n. 4, p. 38 - 40, jul./ago. 1996.

* Normas recomendadas para uso no âmbito da Universidade de São Paulo, com base no documento "Referencias Bibliográficas: exemplos", emanados do Conselho Supervisor do Sistema Integrado de Bibliotecas da USP, em reunião de 20 de setembro de 1990. 
7. BENTLEY, E. M.; ELLWOOD, R. P.; DAVIES, R. M. Factors influencing the amount of fluoride toothpaste applied by the mothers of young children. $\mathbf{B r}$ Dent J, v. 183, n. 11/12, p.412-4, Dec. 13-27, 1997.

8. BRASIL. Ministério da Saúde. Secretaria Nacional de Vigilância Sanitária. Portaria $n^{\circ} 2220$ de dezembro de 1989. Disponível na internet. www.saude.gov.br/sps/areastecnicas/bucal/dados/fluor/port22vig.htm. Acesso em: 14/07/2004.

9. BRASIL. Ministério da Saúde. Programa Brasil Sorridente, Brasília, 2004. Disponível na internet. www.saude.gov.br . Acesso em: 14/07/2004.

10.BUISCHI,Y. P.; AXELSSON, P. Controle mecânico da placa dental realizado pelo paciente. In: ABOPREV: promoção de saúde bucal. São Paulo, Artes Médicas, 1997.cap. 6, p. 115-27.

11. BUZALAF, M. A. R., et al. Association between the early use of toothpaste and other variables with dental fluorosis: a transversal retrospective study. Rev Fac Odontol Bauru, v.10, n. 3, p. 196-200, jul./set. 2002.

12. CHAVES, S. C. L.; VIEIRA-DA-SILVA, L. M. A. efetividade do dentifrício fluoretado no controle da cárie dental: uma meta-análise. Rev Saúde Pública, v.36, n. 5, p. 598-606, 2002.

13. CONRADO, C. A. et al. Efeito de um programa educacional direto relacionado com a saúde bucal de escolares do município de Maringá, PR. Odontol Clín, v.7, p.21 -30, 1997.

14. CURY, J. A.; VILLENA, R. S. Flúor - aplicação sistêmica, In: Correa, M S N P, Odontologia na primeira infância, 1998. Cap. 24, p. 291 -314. 
15. CURY, J. A. O uso do flúor e controle da cárie como doença. In: BARATIERI, L. N. et al. Odontologia restauradora: fundamentos e possibilidades. São Paulo, Ed. Santos, 2001. Cap.2, p. 31-68.

16. CURY, J. A. Dentifrícios: como escolher e indicar. In: CARDOSO, R. J. A.; GONÇALVES, E.A. N. Odontologia 4 : odontopediatria prevenção, São Paulo, Artes Médicas /APCD, 2002. Cap. 16, p 281 -295.

17.DUARTE, F. F.; PISANESCHI, E.; CURY, J. A. Avaliação do flúor dos dentifrícios mais consumidos no Brasil e comercializados nas cinco regiões do país. Rev ABOPREV, v.2, n. 2,p.3-10, nov. 1999.

18. FELDENS, E. G. et al. Avaliação da utilização de dentifrícios fluoretados por crianças de 2 a 5 anos de idade de três escolas de Porto Alegre. J Bras Odontopediatr Odontol Bebê, v.4, n. 21, p.375-82, 2001.

19. FRAZÃO, P.; NARVAI, P.C. Promoção de Saúde Bucal em escolas. In: Universidade de São Paulo, Faculdade de Saúde Pública, Disciplina de odontologia preventiva e saúde pública: Manual do aluno. São Paulo, Departamento de prática de Saúde Pública, 1996.

20.GARCIA, P.P.N.S.; CORONA, S. A. M.; VALSECKI JÚNIOR, A. Educação e motivação/ Impacto de um programa preventivo com ênfase na educação de hábitos de higiene oral. Rev odontol UNESP, v. 27, n. 20, p.393-403, jul./dez. 1998.

21.GIBSON, S.; WILLIAMS, S. Dental caries in pre-school children: associations with social class, toothbrushing habit and consumption of sugar and sugar-containing foods. Caries Res, v.33, n.2, p. 101- 3, 1999.

22. GOMES FILHO, I. S. et al. Avaliação de um programa preventivo de saúde bucal em pré-escolares. Rev Odonto Ciência, n. 27, p.221 -32, 1999. 
23. GOSUEN, L. C., A importância do reforço constante na conscientização e motivação em higiene bucal, Rev Paulista de Odontologia, v 19, n. 5, p. $30-2$, set./out. 1997.

24. HOLT, R. D. et al. Enamel opacities and dental caries in children who used a low fluoride toothpaste between 2 and 5 years of age. Int Dent J, v. 44, p.331- 41, 1994.

25.KOO, H.; CURY, J. A. Avaliação in situ de um dentifrício contendo MFP/DCPD na incorporação de flúor e remineralização no esmalte dental humano. Rev Odontol Univ São Paulo, v. 13, n. 3, p. 245- 9, jul./set. 1999.

26. KRAMER, P. F.; FELDENS, C. A.; ROMANO, A.R. Tratamento não invasivo. In: Promoção de saúde bucal em odontopediatria. São Paulo, Artes Médicas, 2000. Cap. 6, p. 91-128.

27. KWON, H. S. Higiene bucodental em crianças. In: GUEDES - PINTO, A. C. Odontopediatria. 6 ed. São Paulo, Ed. Santos, 2000. Cap. 28 p. 475 -94.

28. LIMA, Y.B.O.; CURY, J.A. Ingestão de flúor por crianças através da água e dentifrício. Rev Saúde Publ, v. 35, n..6, p. 576-81, dez. 2001.

29. LEAL, S. C.; BEZERRA, A. C. B.; TOLEDO, O. A. Avaliação da eficácia do ensinamento de métodos de escovação dentária em crianças préescolares. Braz Dent J, v.13, n.2, p.133- 6, 2002.

30. LONG, S. R.; SANTOS, A. S.; NASCIMENTO, C. M. O. Avaliação da contaminação de escovas dentais por enterobactérias. Rev Odontol Univ Santo Amaro, São Paulo, n. 1, p. 21- 25, jan./jun. 2000. 
31. LOPES L. F. Z.; MORITA, M. C. Higiene bucal: mudanças de conhecimento e hábitos de uma geração para outra em uma população de baixa renda. Rev Semina, v.18, p. 25-33, fev. 1997. /edição especial/.

32. MALTZ, M. Cárie dental: fatores relacionados. In: PINTO, V. G. Saúde bucal coletiva, 4 ed., São Paulo, Ed. Santos, 2000.

33. MALTZ, M.; CARVALHO, J. Diagnóstico da doença cárie. In: KRIGER, L. et al. Promoção de saúde bucal. São Paulo, Artes Médicas,1997.

34.MOSS, S. J. Crescendo sem cárie. São Paulo, Quintessence books, 1996.

35. MOURA, L. F. A. D.; REBELO, M. C. C. B. L.; MOURA, M. D.; ARÊA LEÃO, V. L. Avaliação da eficácia de métodos de higiene bucal em bebês. JBP- J Bras Odontopediatr Odontol Bebê, Curitiba, v. 3, n.12, p. 141- 6, abr./maio 2000.

36.MOYSÉS, S. T.; WATT, R. Promoção de saúde bucal. Definições. In: BUISCHI, Y. P. Promoção de saúde bucal na clínica odontológica. São Paulo, Artes Médicas, 2000.

37. NARVAI, P. C. Cárie dentária e flúor: uma relação do século XX. Ciência \& Saúde Coletiva, v. 5, n. 2, p. 381- 92, 2000.

38. NAVARRO, R. S.; ESTEVES, G. V.; YOUSSEF, M. N. Estudo clínico do comportamento de escolares mediante escovação supervisionada e motivação no controle de placa bacteriano. Rev Odontol Univ São Paulo, v. 10, n.2, p. 153-7, abr./jun. 1996.

39. OLIVEIRA J. et al. Uso precoce dos dentifrícios fluoretados e risco de fluorose dentária. Arq Odont, v.37, n 2, p 189- 98, jul./dez. 2001. 
40.PEIXOTO, S. S.; BASTOS, J. R. M. É possível sorrir: programa preventivo e educativo. Ribeirão Preto, Ed. Villimpress, 1998.

41.PINTO, E. D. R.; PAIVA, E. M. M.; PIMENTA, F. C. Viabilidade de microorganismos anaeróbicos da cavidade bucal em escovas dentárias. Periodontia, v.6, n.1, p.8-12, jan./jun. 1997.

42. PINTO, V. G. Prevenção da cárie dentária: dentifrícios com flúor. In:_ Saúde bucal coletiva, 4 ed. São Paulo, ed. Santos, 2000.Cap. 13 , p. 353-95.

43. PUPPIN-RONTANI, R. M.; CORREA-KASSAWARA, A. B.; DELGADORODRIGUES, C. R. Influence of socioeconomic level and dentifrice brand on the oral hygiene habits and the fluoride dentifrice ingestion. $\mathbf{J}$ Clin Pediatr Dent, v. 26,n.3,p. 319-25, 2002.

44. QUIRYNEN, M et al.Can toothpaste or a toothbrush with antibacterial tufts prevent toothbrush contamination? J Periodontol, v.74, n. 3, p. 312-22, 2003.

45. RAMONA F. C. T.; PETRY, P. C. Motivação no controle do biofilme dental e sangramento gengival em escolares. Rev Saúde Públ, v.36, n. 5, p. 6347, 2002.

46. ROSSETTI, H. Saúde para a odontologia, São Paulo, Ed. Santos, 1999.

47. SANTA CATARINA. BLUMENAU, Câmara Municipal, Lei n. 3979/1991 de 19/12/1991. Disponível na internet: www.blumenau.com.br . Acesso em: 03/05/2004.

48. SÃO PAULO. LEME, Secretaria Municipal de Saúde. Nossa água traz saúde - pacto XXI, Leme, 2004. 
49. SÃO PAULO. Secretaria de Estado da Saúde. Recomendações sobre o uso de produtos fluorados no âmbito do SUS/SP em função do risco de cárie dentária, São Paulo, 2000. Disponível na internet: www.saude.sp.gov.br . Acesso em: 21/02/2004.

50.SATO, H. K.; FORNAZIEIRO, C. C.; WALTER, L. R. F. Escovação dentária e o risco de fluorose em crianças. Rev Semina, v.18, p. 7-14, fev. 1997. /edição especial/.

51.SILVA, M. F.A. Prevenção da cárie dentária. In: PINTO, V. G., Saúde bucal coletiva, São Paulo, ed. Santos, 2000. Cap.13, p 353-81.

52. SILVA, M. F. A. et al. The effect of a triclosan/coplolymer/fluoride liquid dentifrice on interproximal enamel remineralization and fluoride uptake. $\mathbf{J}$ Am Dent Assoc v.135, p. 1023 - 9. 2004.

53.SILVEIRA, E. G.; SILVA, R. H. H.; ALMEIDA, I. C. S. Avaliação de uma metodologia para um programa educativo-preventivo em saúde bucal para escolares. Rev Paul Odont, v. 20, n. 2, p. 22-7, mar./abr. 1998.

54.SILVEIRA, C. S. et al. Avaliação da eficiência do porta - escovas na prevenção da contaminação de escovas dentais por coliformes fecais e parasitas intestinais. Rev CROMG, v. 8, n. 1, p. 65-8, 2002.

55.SILVEIRA, J. L. G. C. et al. Avaliação do uso e acondicionamento de escovas dentárias em creches, disponível na internet: www.odontologiainfantil.com.br, Acesso em: 13 de dezembro de 2003).

56.SVANBERG, M. Contamination of toothpaste and toothbrush by streptococcus mutans. Scand J Dent Res, v.86, n. 5, p. 412-4, sept. 1978. 
57.TAJI, S.S.; ROGERS, A. H. ADRF trebitsch scholarship. the microbial contamination of toothbrushes. a pilot study. Aust Dent J, v.43, n.2, p. 12830, 1998.

58. TEN CATE, J. M., Review on fluoride with special emphasis on calcium fluoride mechanisms in caries prevention. Eur J Oral Sci, v. 105, p. 461-5, 1997.

59.TERDPHONG-TRIRATANA D. D. S. et al., Clinical effect of a new liquid dentifrice containing triclosan/copolymer on existing plaque and gingivitis. $\mathbf{J}$ Am Dent Assoc, v.133,n. 2, p. 219- 25, 2002.

60.VANOBBERGEN, J. et al. The effectiveness of a 6-year oral health education program for primary schoolchildren Community Dent Oral Epidemiol, v.32, n. 3, p. 173 - 82, 2004.

61. VILHENA, F. V., Odontologia escolar, Bauru, S. e., 1998.

62. VILHENA, F. V. et al. Programa educativo preventivo no vale do paraíba: uma realidade. In: Jornada odontológica de Bauru Prof. Dr. Clóvis Monteiro Bramante; Anais , Bauru, FOB-USP, 2001. p. 30, t. 12.

63. VILHENA, F.V. Turma do escovinha, Rio de Janeiro,Fundação da Biblioteca Nacional, 2000/ Registro : 213.544, livro 372 , f. 204/.

64. VILHENA, F. V. Turma do escovinha, personagens usados em programas de saúde coletiva. In: ENCONTRO CIENTÍFICO DE PÓS GRADUAÇAO, 5., Bauru, 2003, Anais. Bauru, HRAC - USP, 2003. p.87.

65. VILHENA, F. V.; SALES PERES, S. H. C.; BASTOS, J. R. M., Proposta de um novo kit para armazenamento e distribuição de escovas de dente e dentifrício para escolares. Odontologia e Sociedade, v .6, n. 1, p 53, 2004. 
66. VILLENA, R. S. An investigation of the transverse technique of dentifrice application to reduce the amount of fluoride dentifrice for young children. Ped Dent, v.22, n. 4, p. 312-7, 2000.

67.WALTER, L. R. F.; FERELLE, A.; ISSAO, M. Condutas clínicas: educativas e preventivas. In: Odontologia para o bebê: odontopediatria do nascimento aos 3 anos. São Paulo, Artes Médicas, 1997. Cap. 12, p. 209218.

68. WARREN, D.P.; RICE, H.C.; TURNER, S. Comparison of plaque removing ability of one standard and two flexible-head toothbrushes. J Dent Hyg, v.78, n. 2, p. 340-2, 2004.

69. WHELTON, H. P. et al. A review of fluorosis in the European Union: prevalence, risk factors and aesthetic issues. Com Den Oral Epid, v.32, p.1 - 9, Apr. 2004. 


\section{ABSTRACT}

The purpose of this study was to evaluate the storage and distribution of school children toothbrushing material. Twenty school children responsible appraisers from Bauru and São José dos Campos participated in the first stage. They answered 2 questionnaires (attachment I e II) about five collective oral health kits. The statistical analysis of this stage was obtained by using Wilcoxon test with confidence level of $95 \%(p<0,05)$. One hundred seventy eight school children from 4-8 years from 2 cities from Brazil (Bauru e Bariri) participated in the second stage and each applied an amount of toothpaste and liquid dentifrice to toothbrushing. A portable laboratory balance weighed the amounts of dentifrices applied and statistical analysis was obtained by using Pearson correlation coefficient and analysis of covariance (Ancova). Tests were performed at confidence level of $95 \%(p<0,05)$. Kit 5 when compared with other kit $(1-4)$ obtained satisfaction and high satisfaction degree. Besides a direct comparison among the kits, kit 5 was obtained a cost 17, $5 \%$ less than kit 4, 23, 3\% than kit 3, 19, 5\% than kit 2 and 35 , $3 \%$ than kit 1 . There was no statistic difference between the use of liquid dentifrice by the children from Bauru and Bariri, and also the ages. The school children from Bauru that received toothbrushing orientation $(0,41 \mathrm{~g})$ used smaller amount of toothpaste than the school children from Bariri received no orientation $(0,48 \mathrm{~g})$. The average of the amount of liquid dentifrice applied by the sample was $0,15 \mathrm{~g}$. The "drop technique" (liquid dentifrice) can pattern a little quantity of dentifrice applied by the school children and kit 5 demonstrated the best storage and distribution of school children toothbrushing material optimizing costs and strategies in oral public health programs. 